Article

\title{
Synthesis, Biological Evaluation, and In Silico Studies of Novel Aminated Xanthones as Potential p53-Activating Agents
}

\author{
Agostinho Lemos ${ }^{1}{ }^{(\mathbb{}}$, Ana Sara Gomes ${ }^{2}{ }^{(}$, Joana B. Loureiro ${ }^{2}$, Pedro Brandão ${ }^{1}(\mathbb{D}$, \\ Andreia Palmeira ${ }^{1,3}$, Madalena M. M. Pinto ${ }^{1,3} \mathbb{D}^{\mathbb{D}}$, Lucília Saraiva ${ }^{2, * \mathbb{D}}$ and \\ Maria Emília Sousa $1,3, *$ (D) \\ 1 Laboratory of Organic and Pharmaceutical Chemistry, Department of Chemical Sciences, \\ Faculty of Pharmacy, University of Porto, Rua de Jorge Viterbo Ferreira, 228, 4050-313 Porto, Portugal; \\ up201002662@ff.up.pt (A.L.); pedrocgbrandao@gmail.com (P.B.); andreiapalmeira@gmail.com (A.P.); \\ madalena@ff.up.pt (M.M.M.P.) \\ 2 UCIBIO/REQUIMTE, Laboratory of Microbiology, Department of Biological Sciences, Faculty of Pharmacy, \\ University of Porto, Rua de Jorge Viterbo Ferreira, 228, 4050-313 Porto, Portugal; \\ anasarag4@gmail.com (A.S.G.); up201407524@ff.up.pt (J.B.L.) \\ 3 CIIMAR-Interdisciplinary Centre of Marine and Environmental Research, University of Porto, \\ Novo Edificio do Terminal de Cruzeiros do Porto de Leixões, Avenida General Norton de Matos, S/N, \\ 4450-208 Matosinhos, Portugal \\ * Correspondence: lucilia.saraiva@ff.up.pt (L.S.); esousa@ff.up.pt (M.E.S.); \\ Tel.: +351-22-0428-584 (L.S.); +351-22-0428-689 (M.E.S.)
}

Academic Editor: Qiao-Hong Chen

Received: 7 May 2019; Accepted: 21 May 2019; Published: 22 May 2019

\begin{abstract}
Xanthone scaffold has been regarded as an attractive chemical tool in the search for bioactive molecules with antitumor activity, and in particular two xanthone derivatives, 12-hydroxy-2,2-dimethyl-3,4-dihydro-2H,6H-pyrano [3,2-b]xanthen-6-one (4) and 3,4-dimethoxy-9oxo-9H-xanthene-1-carbaldehyde (5), were described as a murine double minute 2 (MDM2)-p53 inhibitor and a TAp73 activator, respectively. The xanthone $\mathbf{5}$ was used as a starting point for the construction of a library of 3,4-dioxygenated xanthones bearing chemical moieties of described MDM2-p53 inhibitors. Eleven aminated xanthones were successfully synthesized and initially screened for their ability to disrupt the MDM2-p53 interaction using a yeast cell-based assay. With this approach, xanthone 37 was identified as a putative p53-activating agent through inhibition of interaction with MDM2. Xanthone 37 inhibited the growth of human colon adenocarcinoma HCT116 cell lines in a p53-dependent manner. The growth inhibitory effect of xanthone $\mathbf{3 7}$ was associated with the induction of G1-phase cell cycle arrest and increased protein expression levels of p53 transcriptional targets. These results demonstrated the potential usefulness of coupling amine-containing structural motifs of known MDM2-p53 disruptors into a 3,4-dioxygenated xanthone scaffold in the design of novel and potent p53 activators with antitumor activity and favorable drug-like properties. Moreover, in silico docking studies were performed in order to predict the binding poses and residues involved in the potential MDM2-p53 interaction.
\end{abstract}

Keywords: antitumor activity; computational docking; MDM2-p53 interaction; xanthones; yeast-based assays

\section{Introduction}

The tumor suppressor p53 acts as a transcription factor, triggering the expression of multiple downstream target genes that play a pivotal role in the regulation of cell cycle arrest, apoptosis, 
senescence, and DNA repair [1-6]. Upon cellular stress stimuli, the activation of the p53 pathway may compromise the tumorigenesis, circumventing the proliferation of damaged cells with oncogenic potential. Inactivation of the p53 function represents one of the most common events in human cancers [7]. In approximately half of all human cancer cells, the p53 inactivation is caused by mutations within the p53 gene (TP53) or by post-translational modifications of its gene product [8]. In those tumors retaining the wild type (wt) p53 function, the tumor suppressor activity of p53 can be abolished by multiple mechanisms [9], mainly by direct interaction between p53 and its primary endogenous inhibitor, the murine double minute 2 (MDM2) protein $[10,11]$. The oncoprotein MDM2 physically interacts with the amino-terminal domain of p53 and negatively regulates its activity by blocking p53-mediated transactivation [12,13], by inducing the export of p53 from nucleus to the cytoplasm [14], and by promoting E3 ubiquitin ligase-mediated p53 degradation via the proteasomal pathway [15,16]. Targeting the MDM2-p53 interaction with small molecules has been regarded an attractive approach for the reactivation of the p53 pathway in wt p53-expressing tumors $[17,18]$. Since the seminal work of Vassilev et al. reporting the discovery of nutlin-3A (1, Figure 1) as the first inhibitor of MDM2-p53 interaction [19], an impressive number of MDM2-p53 disruptors from a huge diversity of chemical families have been identified in recent years, entering some of them into clinical trials [20,21].

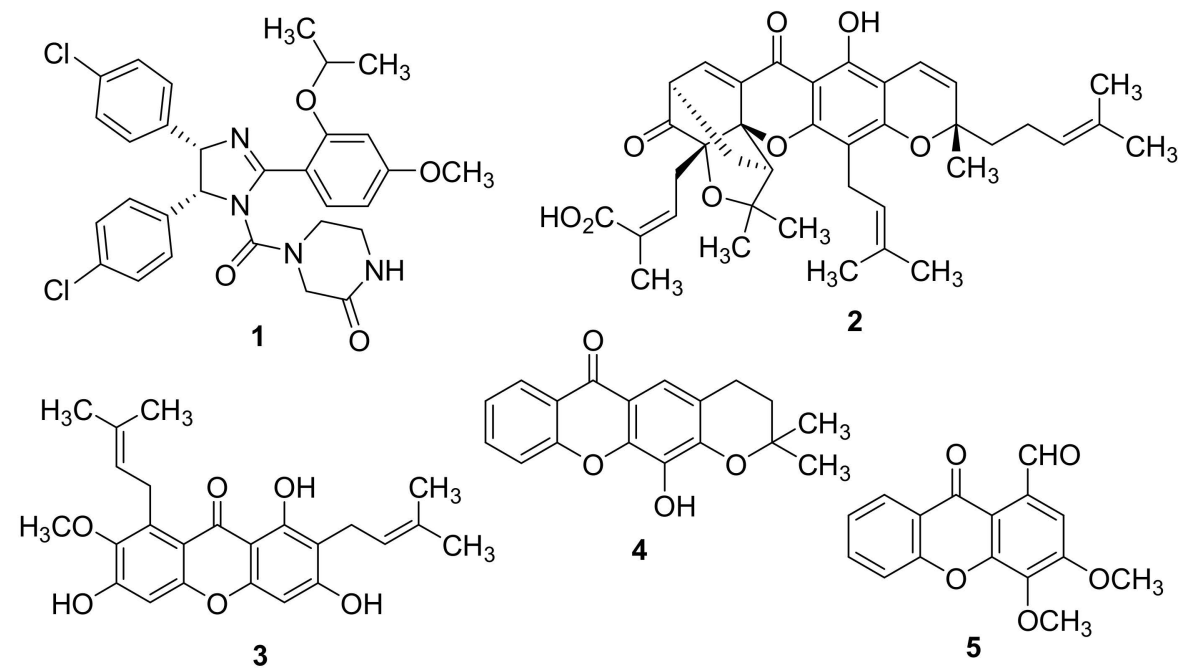

Figure 1. Chemical structures of nutlin-3A (1), gambogic acid (2), $\alpha$-mangostin (3), 12-hydroxy-2,2dimethyl-3,4-dihydro-2H,6H-pyrano[3,2- $b$ ]xanthen-6-one (4), and 3,4-dimethoxy-9-oxo-9H-xanthene1-carbaldehyde (5).

Xanthones represent a privileged class of compounds with a multiplicity of biological activities, in particular with antitumor activity against several human tumor cell lines [22-36]. Intriguingly, our research group has demonstrated that the antitumor activity of some derivatives can be correlated to the disruption of the MDM2-p53 complex and the activation of a p53-dependent pathway $[30,31]$. In fact, implementing a yeast-based assay, the naturally occurring xanthones gambogic acid (2, Figure 1) and $\alpha$-mangostin (3, Figure 1) were found to revert the inhibitory effect of MDM2 on p53-induced growth inhibition and on p53 transcriptional activity [30]. The synthetic xanthone 12-hydroxy-2,2-dimethyl-3,4-dihydro-2H,6H-pyrano [3,2-b]xanthen-6-one (4, Figure 1) was identified as a potential MDM2-p53 disruptor, using an in silico virtual screening strategy against MDM2 protein and a yeast-based assay [31]. Its molecular mechanism was corroborated in MDM2-overexpressing human tumor cell lines with wt p53. In fact, xanthone 4 selectively upregulated the p53 transcriptional activity, increasing the protein expression levels of p53-target genes in HCT116 human colon adenocarcinoma cells [31]. Nevertheless, xanthone 4 is highly hydrophobic and poorly water soluble, which could limit its in vivo use. Interestingly, Chen and co-workers explored the antitumor activity of xanthone 4 either in combination or hybridized with 5,6-dimethylxanthone-4-acetic acid (DMXAA) [37], a xanthone derivative with tumor-vascular disrupting activity. A very recent study reported the discovery of 
3,4-dimethoxy-9-oxo-9H-xanthene-1-carbaldehyde (5, Figure 1) as a new TAp73 activator via disruption of its interaction with both MDM2 and mutant p53 [36].

Herein, based on the 3,4-oxygenated pattern of substitution of xanthones 4 and 5 (Figure 2A), and on chemical moieties derived from known MDM2-p53 disruptors, namely the molecules 1 [19], 6 [38], 7 [39], and 8 [40] (Figure 2B), we followed a molecular hybridization approach for the construction of novel 3,4-oxygenated xanthone derivatives (Figure 2D). In the present work, we opted to synthesize a library of aminated xanthones (Figure 2D) via a strategy of reductive amination of the xanthone $\mathbf{5}$ with a set of commercially available amine precursors (9-19) containing structural motifs of MDM2-p53 disruptors (Figure 2C). The introduction of amine moieties in the xanthone scaffold may contribute to a potential enhancement of drug-like properties, a critical parameter for the identification of promising drug candidates. The ability of the synthesized ligands to disrupt the MDM2-p53 interaction and to activate a p53-dependent pathway was further investigated using the previously established yeast-based assay and in human cancer cell lines. In silico docking studies were performed in order to predict the binding poses and residues involved in the potential MDM2-p53 interaction.

\section{Results and Discussion}

\subsection{Chemistry}

\subsubsection{Synthesis of 3,4-dimethoxy-9-oxo-9H-xanthene-1-carbaldehyde (5)}

In the present work, xanthone $\mathbf{5}$ was used as a starting precursor for the synthesis of a set of aminated xanthones with a 3,4-dioxygenated pattern of substitution. Recently, the multi-step synthesis of compound 5 has been reported [36] as consisting in: (i) a Friedel-Crafts acylation of 1,2,3-trimethoxybenzene (20) with the commercially available reagent 2-methoxybenzoyl chloride (21); (ii) an intramolecular nucleophilic aromatic substitution of (2-hydroxy-3,4-dimethoxyphenyl) (2-methoxyphenyl)methanone (22) and consecutive regioselective demethylation of the methoxy group at position C-4 under conventional heating; (iii) a Duff formylation at position C-1 of 4-hydroxy-3methoxy-9H-xanthen-9-one (23); and (iv) a methylation of the hydroxyl group at position C-4 of 4-hydroxy-3-methoxy-9-oxo-9H-xanthene-1-carbaldehyde (24) (Scheme 1A). The difficulty in achieving a regioselective demethylation at position C-4 necessary for Duff formylation at position C-1 demanded the planning of an optimized synthetic route more appropriate for scaling-up. We hypothesized that the implementation of an analog precursor of 20 with a suitable substituent at position C-1 might provide a useful alternative for the synthesis of $\mathbf{5}$, avoiding the troublesome demethylation and Duff formylation processes. Herein, the commercially available 1,2,3-trimethoxy-5-methylbenzene (25) was selected for the Friedel-Crafts acylation with the acyl chloride $\mathbf{2 1}$ and the Lewis acid aluminum chloride to furnish the intermediate (2-hydroxy-3,4-dimethoxy-6-methylphenyl)(2-methoxyphenyl)methanone (26). Subsequent intramolecular nucleophilic aromatic substitution followed by elimination of methanol under basic conditions and microwave (MW) irradiation provided the 3,4-dimethoxy-1-methyl9H-xanthen-9-one (27) in good yield quantity. This two-step methodology for the construction of xanthone analogues of $\mathbf{2 7}$ has been previously described in the literature [32,41-43]. With the application of MW methodology in the basic cyclization of $\mathbf{2 6}$ instead of the conventional heating employed in the synthesis of $\mathbf{2 3}$, the reaction time was reduced from $48 \mathrm{~h}$ to $6 \mathrm{~h}$. Furthermore, xanthone 27 was obtained in higher reaction yield under MW irradiation (63\% yield (27) vs. 38\% yield (23)). Subsequently, the Vohl-Ziegler bromination of 27, using dibenzoyl peroxide (DBP) and $\mathrm{N}$-bromosuccinimide (NBS) as a radical initiator and a brominating agent, respectively, afforded the 1-(dibromomethyl)-3,4-dimethoxy-9H-xanthen-9-one (28) as the major product. A solvolytic displacement of bromine atoms of the xanthone 28 was effectively attained using 1-butyl-3methylimidazolium tetrafluoroborate and water, under conventional heating, and furnished xanthone 5 in $64 \%$ yield quantity (Scheme 1B). Of note, the two-step procedure of Vohl-Ziegler bromination and subsequent solvolytic displacement required lower reaction times ( $4.5 \mathrm{~h}$ ( 2 steps from 27 to 5 ) vs. $54 \mathrm{~h}$ ( 2 steps from 23 to 5 ) and allowed the preparation of xanthone 5 in higher reaction yields ( $51 \%$ yield ( 2 steps from 27 to 5) vs. $28 \%$ yield (2 steps from 23 to 5)), compared to the Duff formylation/methylation 
pathway. Overall, the replacement of starting precursor 20 by the methylated derivative 25 at position $\mathrm{C}-1$ of the aromatic ring was critical for the successful optimization of the preparation of xanthone 5 .
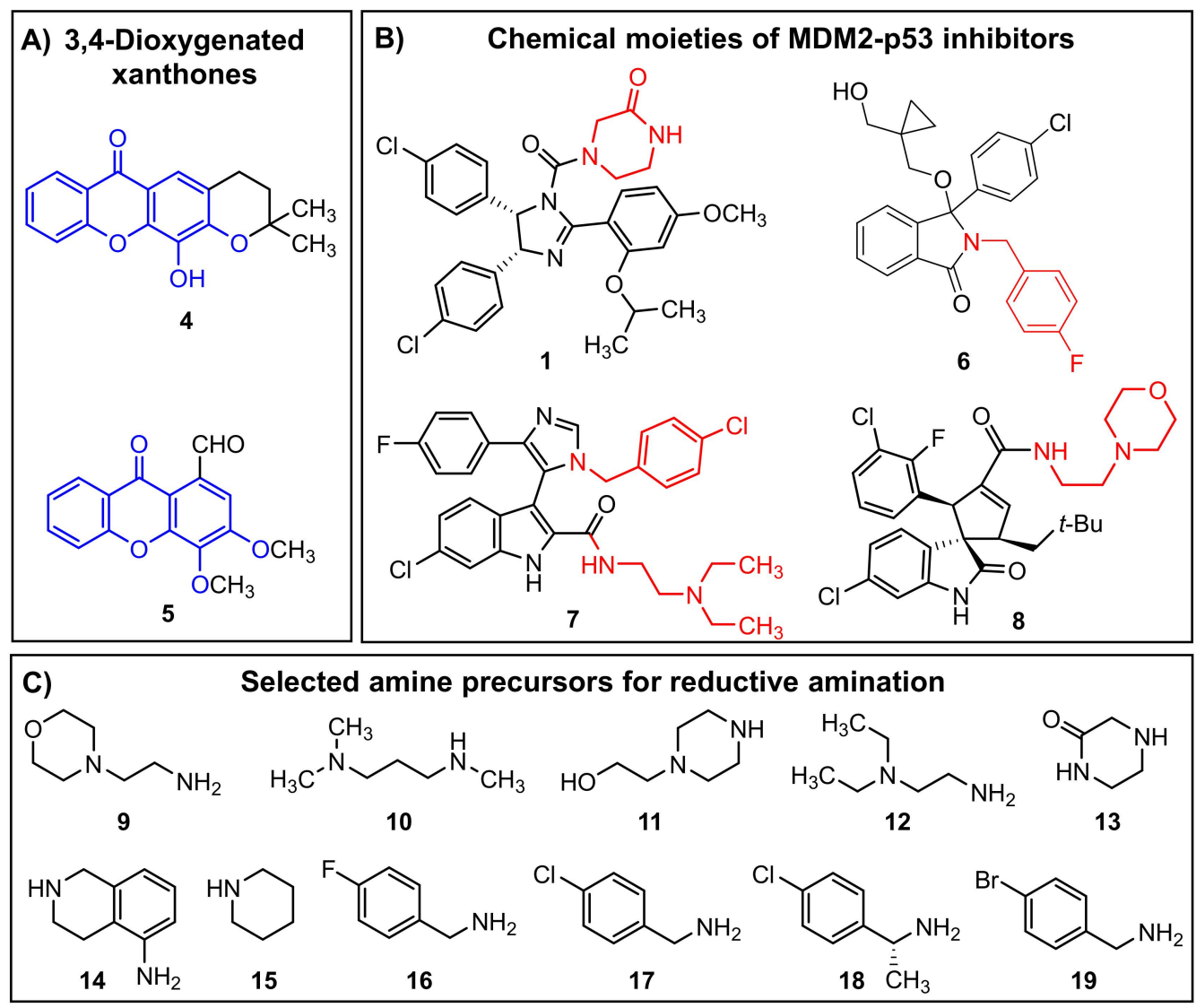

D)

3,4-Dioxygenated xanthones conjugated with chemical moieties of MDM2-p53 inhibitors

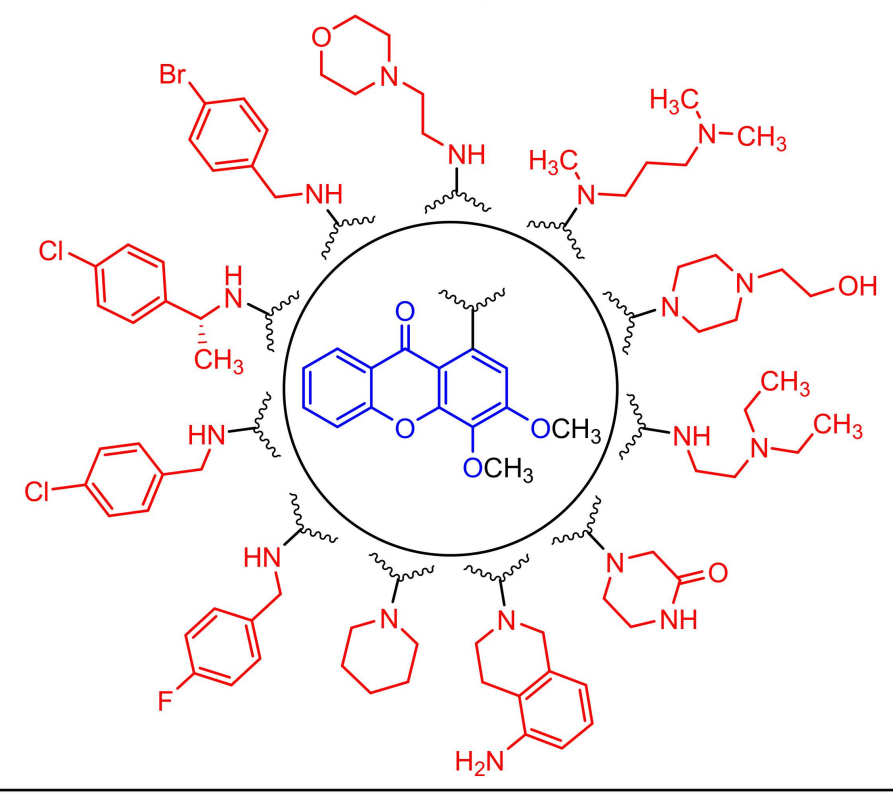

Figure 2. Strategy of molecular hybridization used for the construction of the library of aminated xanthones (D) by conjugation of the 3,4-dioxygenated substitution pattern of xanthones 4 and 5 (A) with the chemical moieties of known murine double minute 2 (MDM2)-p53 inhibitors (C), namely the molecules $1\left(\mathrm{IC}_{50}=0.09 \mu \mathrm{M}\right), 6\left(\mathrm{IC}_{50}=2.6 \mu \mathrm{M}\right), 7\left(\mathrm{~K}_{\mathrm{I}}=0.656 \mu \mathrm{M}\right)$, and $8\left(\mathrm{~K}_{\mathrm{I}}=0.023 \mu \mathrm{M}\right)(\mathbf{B})$. 
A)
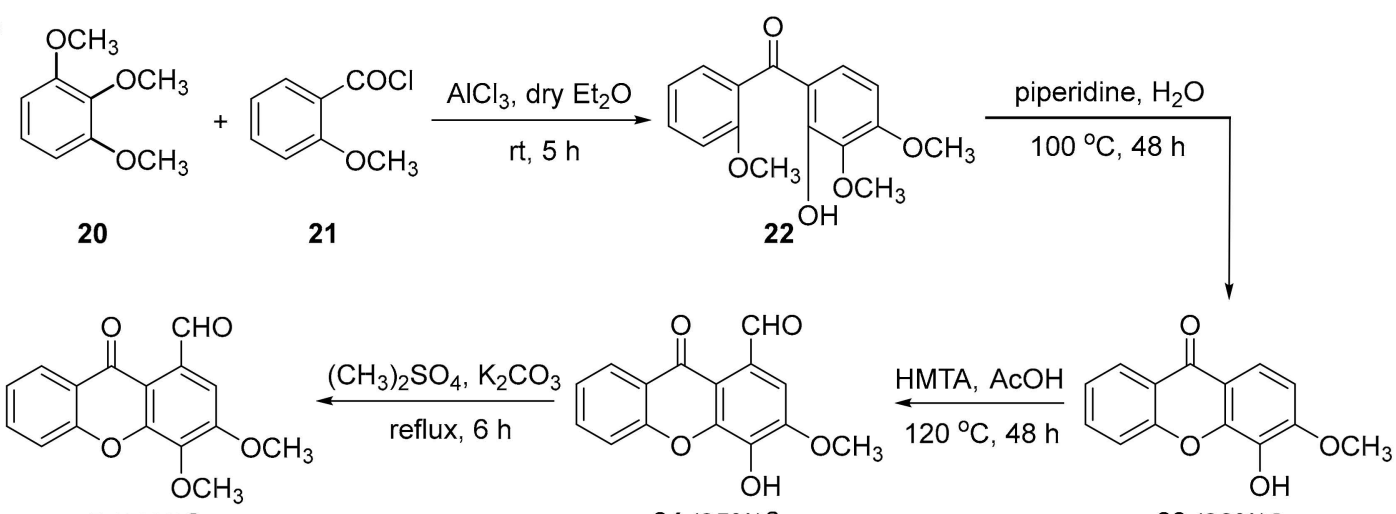

$5(80 \%)^{\mathrm{a}}$

$24(35 \%)^{a}$

$23(38 \%)^{a}$<smiles></smiles>

Scheme 1. (A) Synthetic route for the preparation of 3,4-dimethoxy-9-oxo-9H-xanthene-1-carbaldehyde (5) from 1,2,3-trimethoxybenzene (20). (B) Optimized synthetic route for the preparation of the xanthone 5 using the starting precursor 1,2,3-trimethoxy-5-methylbenzene (25). The compound numbering used concerns the nuclear magnetic resonance (NMR) assignments. Note: $[\mathrm{BmIm}] \mathrm{BF}_{4}=1$-butyl3-methylimidazolium tetrafluoroborate; DBP = dibenzoyl peroxide; HMTA = hexamethylenetetramine; NBS $=N$-bromosuccinimide. ${ }^{\text {a }}$ Isolated yields.

\subsubsection{Synthesis of a Library of Aminated Xanthones (30-40)}

A library of aminated xanthones 30-40 with a 3,4-dioxygenated pattern of substitution was obtained through a one-pot reductive amination of xanthone 5 with the appropriate amine precursors 9-19 (Scheme 2). In one-pot reductive aminations, the selection of the reducing agent is critical for their efficiency, since a suitable agent must reduce the Schiff base intermediate selectively over the carbonylated compounds. As an attempt to investigate the best reaction conditions, a solid-supported reactant containing borohydride $\left(\mathrm{MP}-\mathrm{BH}_{4}\right)$ combined with methanol were initially employed, since it was successfully used in the reductive amination of a xanthone derivative (data not shown). When these conditions were applied to the reductive amination of 5 , the starting precursor was not completely consumed and the alcohol derivative 1-(hydroxymethyl)-3,4-dimethoxy-9H-xanthen-9-one (29) was the major product formed. The replacement of the above-mentioned conditions by the milder reducing agent sodium triacetoxyborohydride $(\mathrm{STAB})$ and the solvent tetrahydrofuran allowed a total consumption of the xanthone 5 , favoring the one-pot amination/reduction pathway. Under the reaction conditions described in the Scheme 2, eleven aminated xanthones 30-40 were successfully synthesized in moderate to good yields (11 examples, $39-73 \%$ yields). 


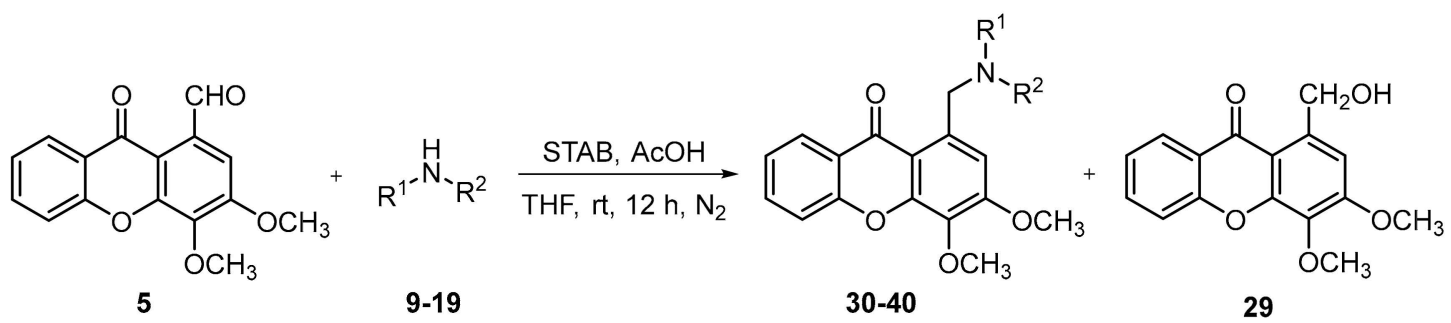<smiles>COc1cc(CNCC(C)N2C[C]OCC2)c2c(=O)c3ccccc3oc2c1OC</smiles>

$30(62 \%)^{a}$<smiles>COc1c(CCN(C)C)cc(CN(C)C)c2c(=O)c3ccccc3oc12</smiles>

$31(65 \%)^{a}$

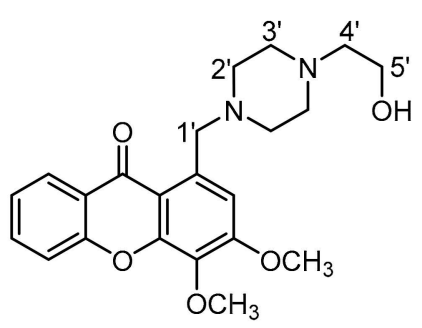

$32(71 \%)^{\mathrm{a}}$<smiles>CCN(CC)C(C)CNCc1cc(OC)c(OC)c2oc3ccccc3c(=O)c12</smiles>

$33(52 \%)^{a}$<smiles>COc1cc(CN2CC(=O)N[C@@H](C)C2)c2c(=O)c3ccccc3oc2c1OC</smiles>

$34(39 \%)^{a}$<smiles>COc1cc(CN2CCc3c(N)cccc3O2)c2c(=O)c3ccccc3oc2c1OC</smiles>

$35(39 \%)^{a}$<smiles>COc1cc(CN2[C][C][C][C]2)c2c(=O)c3ccccc3oc2c1O</smiles><smiles>COc1cc(CNCc2ccc(F)cc2)c2c(=O)c3ccccc3oc2c1OC</smiles>

$37(61 \%)^{a}$<smiles>COc1cc(CNCc2ccc(Cl)cc2)c2c(=O)c3ccccc3oc2c1O</smiles><smiles>COc1cc(/C=N\C(C)[C@@H](C)c2ccc(Cl)cc2)c2c(=O)c3ccccc3oc2c1OC</smiles>

$39(65 \%)^{a}$<smiles>COc1cc(CNCc2ccc(Br)cc2)c2c(=O)c3ccccc3oc2c1OC</smiles>

$40(73 \%)^{a}$

Scheme 2. Reductive amination of $\mathbf{5}$ with appropriate amine precursors 9-19 for the synthesis of aminated xanthones $\mathbf{3 0 - 4 0}$ with a 3,4-dioxygenated substitution pattern. The compound numbering used concerns the NMR assignments. ${ }^{a}$ Isolated yields.

The structure elucidation of the xanthones $\mathbf{5}$ and $\mathbf{2 7 - 4 0}$ was established on the basis of highresolution mass spectrometry (HRMS) (Figures S1-S15) and nuclear magnetic resonance (NMR) techniques (Figures S16-S45). The ${ }^{13} \mathrm{C}-\mathrm{NMR}$ assignments were determined by bidimensional heteronuclear single quantum coherence (HSQC) and heteronuclear multiple bond correlation (HMBC) experiments (Supplementary Materials). 


\subsection{Biological Activity Evaluation}

2.2.1. Effect of Synthesized Xanthone Derivatives 30-40 on the MDM2-p53 Interaction Using A Yeast-Based Screening Assay

Our group has previously developed a yeast-based screening assay to search for potential inhibitors of the MDM2-p53 interaction [30,31,44-46]. In this yeast cell system, the expression of human wt p53 induces a growth inhibition proportional to the degree of its activity (Figure 3, p53, dimethyl sulfoxide (DMSO)). On the other hand, this p53 inhibitory effect is reversed by yeast co-expression of human MDM2 (Figure 3, MDM2-p53, DMSO). This established yeast screening assay was used to study the potential inhibitory effect of $1-20 \mu \mathrm{M}$ of xanthone derivatives $\mathbf{3 0}-\mathbf{4 0}$ on the MDM2-p53 interaction. Figure 3 represents the maximal effect achieved with xanthone derivatives $\mathbf{3 0 - 4 0}$ at $10 \mu \mathrm{M}$. The results showed that only the xanthone 37 caused a significant reversion of the inhibitory effect of MDM2 on p53 (77.01 $\pm 7.35 \%$ of reversion, $n=3)$, with an almost complete reestablishment of the p53 growth inhibitory effect ( $63.55 \pm 4.26 \%$ vs. $69.22 \pm 2.23 \%$; Figure 3, DMSO-treated p53-expressing yeast vs. xanthone 37-treated MDM2-p53-expressing yeast). It should be noted that xanthone 37 did not interfere with the growth of control yeast (transformed with empty vectors) or yeast expressing human p53 alone (data not shown). As such, these results indicated that the xanthone 37 behaved as a potential p53-activating agent through inhibition of interaction with MDM2, and it was, therefore, selected for further investigation in human cancer cells.

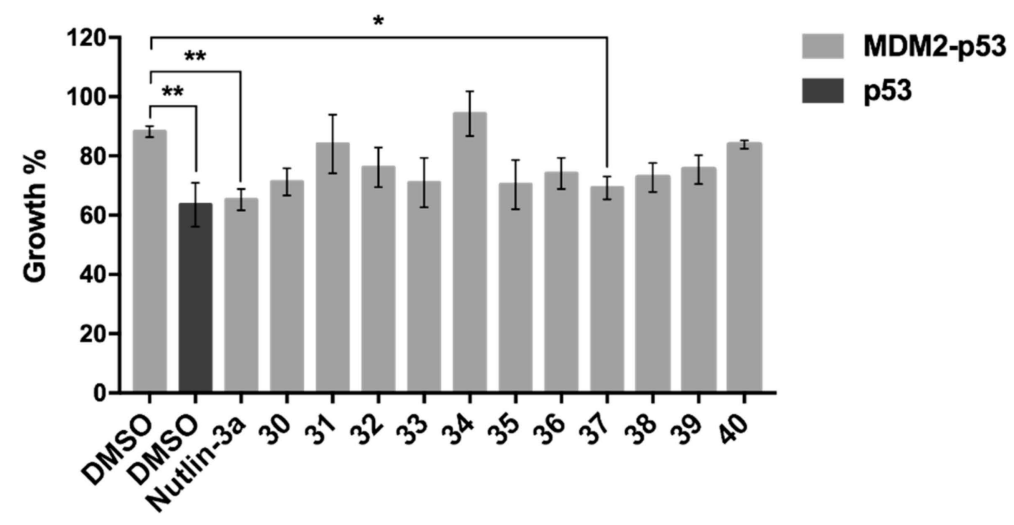

Figure 3. Effect of xanthones $\mathbf{3 0 - 4 0}$ on the MDM2-p53 interaction using a yeast-based assay. Effect of $10 \mu \mathrm{M}$ xanthone derivatives $\mathbf{3 0 - 4 0}$ and nutlin-3A on the growth of yeast co-expressing p53 and MDM2 after $42 \mathrm{~h}$ treatment; results were plotted setting as $100 \%$ the growth of yeast transformed with the empty vector (control yeast); nutlin-3A (inhibitor of the MDM2-p53 interaction) was used as positive control. Data are mean \pm standard error of the mean (SEM) of three independent experiments; mean values were statistically analyzed by one-way analysis of variance (ANOVA) with Tukey's multiple comparisons test, with significant differences from yeast co-expressing MDM2-p53 treated with DMSO. Note: ${ }^{*} p<0.05 ;{ }^{* *} p<0.01$.

\subsubsection{Evaluation of the Antitumor Activity of Xanthone 37 in Human Cancer Cell Lines}

Using the sulforhodamine B (SRB) assay, it was confirmed that xanthone 37 inhibited the growth of human HCT116 $\mathrm{p}^{+/+}$colon cancer cells, with an $\mathrm{IC}_{50}$ (concentration that causes $50 \%$ growth inhibition) value of $8.67 \pm 0.59 \mu \mathrm{M}(n=4)$, and of the MDM2-overexpressing human HepG2 liver carcinoma cells, with an $\mathrm{IC}_{50}$ value of $18.95 \pm 0.39 \mu \mathrm{M}(n=4)$, after $48 \mathrm{~h}$ treatment.

To evaluate the dependency of the antitumor activity of xanthone 37 on the p53 pathway, we next determined the impact of xanthone 37 on the colony forming ability of HCT116 p53 ${ }^{+/+}$cells and on the respective p53-knockout (HCT116 $\mathrm{p53}^{-/-}$), using a colony formation assay (Figure 4A). The results showed a significant reduction of the growth inhibitory activity of xanthone 37 , at 3-5 $\mu \mathrm{M}$ in HCT116 $\mathrm{p} 53^{+/+}$cells, demonstrating a p53-dependent antitumor effect of xanthone 37. Accordingly, 10 and $20 \mu \mathrm{M}$ of xanthone 37 caused a G1-phase cell cycle arrest in HCT116 p53 $3^{+/+}$cells, but not in HCT116 
p53 $3^{-1-}$ cells (Figure 4B) after $24 \mathrm{~h}$ treatment. It is of note that apoptosis analysis was also investigated by Annexin- $\mathrm{V}$ assay; nevertheless, apoptotic events were not detected at 10 and $20 \mu \mathrm{M}$ of xanthone 37 , after 24 and $48 \mathrm{~h}$ treatment. In accordance with these results, we also observed that xanthone 37 upregulated the protein expression levels of MDM2, p53, and p21, in HCT116 p53 $3^{+/+}$cells for $24 \mathrm{~h}$ treatment (Figure 4C).

A
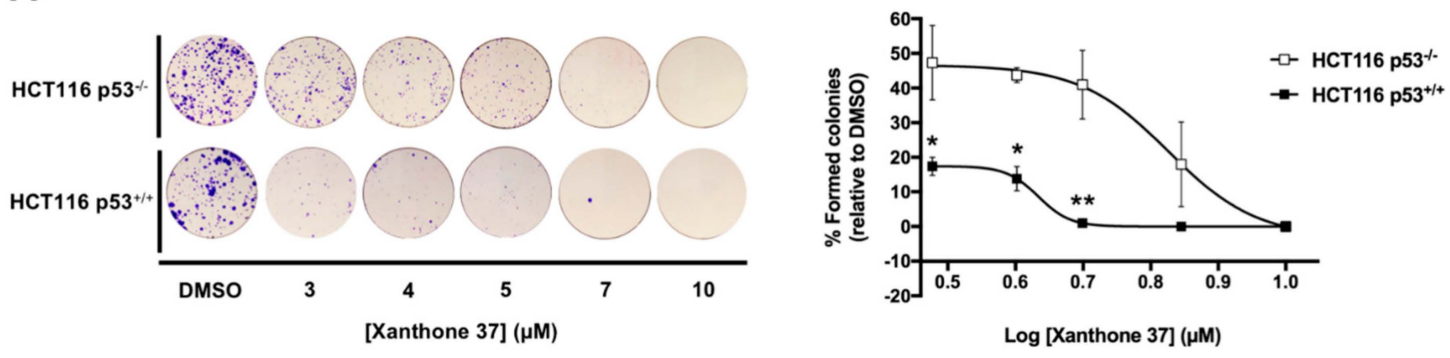

B
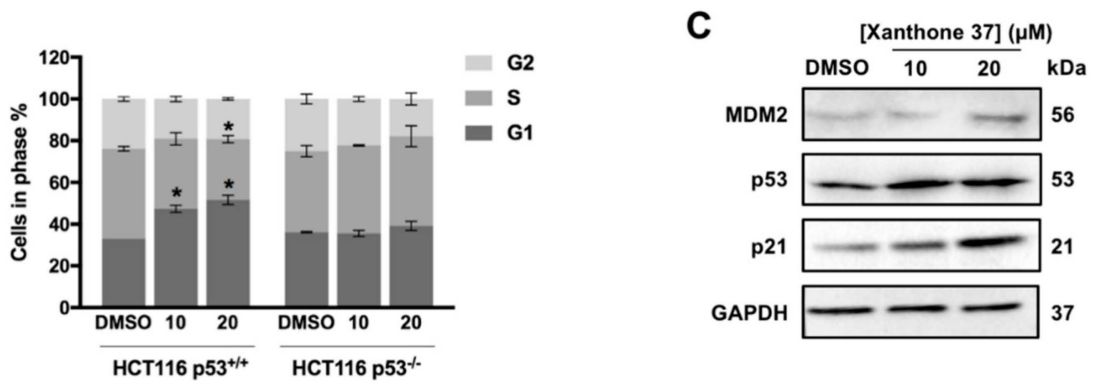

Figure 4. Xanthone 37 inhibits the colony forming capability of HCT116 cells through induction of cell cycle arrest and in a p53-dependent manner. (A) Evaluation of colony forming ability in HCT116 p53 ${ }^{+/+}$ and HCT116 p53-/- colon cancer cells after 11 days treatment with 3-10 $\mu \mathrm{M}$ of xanthone 37; results were plotted setting as $100 \%$ the colonies formed after treatment with dimethyl sulfoxide (DMSO). (B) Effect of 10 and $20 \mu \mathrm{M}$ of xanthone 37 on cell cycle progression of HCT116 p53 $3^{+/+}$and HCT116 p53-/- cells, after $24 \mathrm{~h}$ treatment. (C) Effect of 10 and $20 \mu \mathrm{M}$ of xanthone 37 on the expression levels of MDM2, p53, and p21 in HCT116 p53 ${ }^{+/+}$cells analyzed by Western Blot after $24 \mathrm{~h}$ treatment. Immunoblots represent one of three independent experiments; Glyceraldehyde 3-phosphate dehydrogenase (GAPDH) was used as loading control. (A,B) Data are mean \pm SEM of three independent experiments; values significantly different from HCT116 $\mathrm{p}^{-/-}$cells using two-way ANOVA with Sidak's multiple comparisons test (A) or DMSO using Student's $t$-test $(\mathbf{B})$ are indicated: ${ }^{*} p<0.05 ;{ }^{* *} p<0.01$.

Altogether, these results indicated that xanthone 37 had an in vitro p53-dependent antitumor activity mediated by induction of cell cycle arrest.

\subsection{In Slico Studies}

It is common knowledge that the amino-terminal (residues 18-26) p53 $\alpha$-helical peptide interacts with a deep hydrophobic cleft within the amino-terminal domain of MDM2 [47]. The MDM2 binding site consists of a large and a small pocket that interact with Phe19/Trp23 and Leu26 of p53, respectively (Figure 5A) [48]. The crystal structure of the MDM2 complexed with the transactivation domain of p53 (Protein Data Bank (PDB) id 1YCR [49]) allowed the visual inspection of the interactions between the Phe19, Trp23, and Leu26 residues of p53 and their respective pockets. Hydrogen-bonding interactions are established between the indole group of Trp23 and carbonyl backbone of Leu54, and between the $\mathrm{NH}$ backbone of Phe19 and the carbamoyl group of Gln72. Additional interactions are established between p53 and Leu57, Gly58, Ile61, Met62, Val75, Va193, and His96 residues of MDM2 (Figure 5B). 

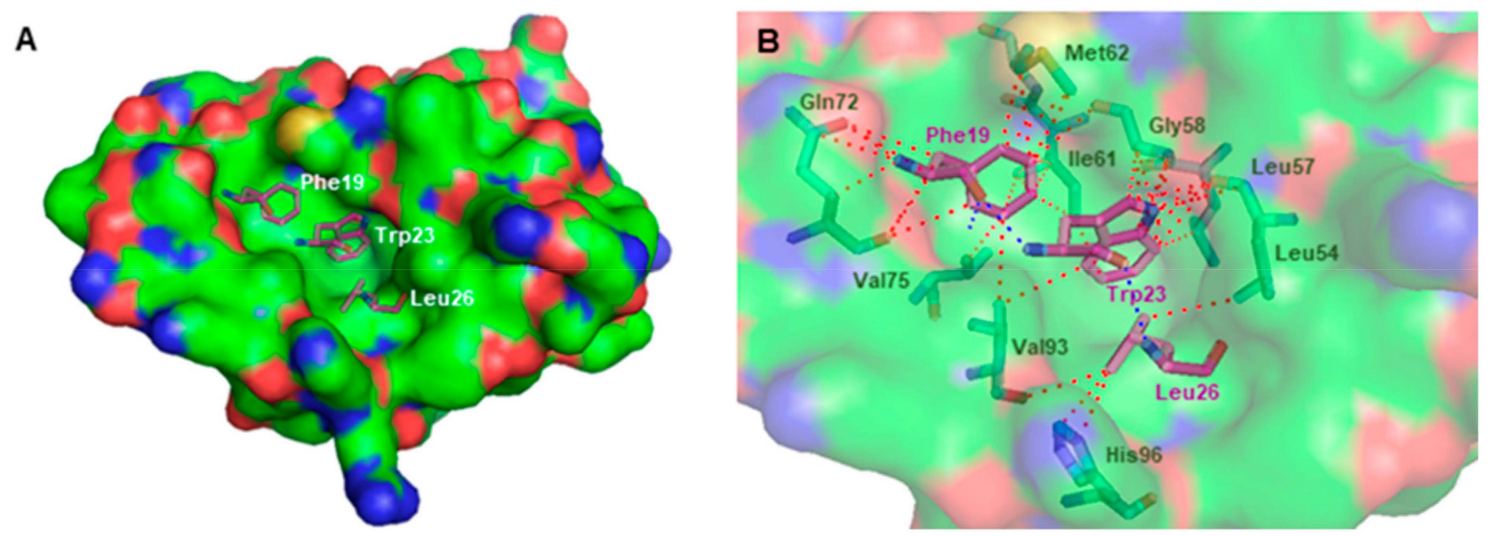

Figure 5. (A) Crystallographic p53 (for simplification, only Phe19, Trp23, and Leu26 residues are represented as purple sticks) bound to the three pockets of MDM2 (solid surface). (B) Binding mode of crystallographic p53 (for simplification, only residues Phe19, Trp23, and Leu26, are represented as purple sticks) in the hydrophobic cleft of MDM2 (transparent surface); MDM2 amino acid residues involved in interactions with p53 are represented as green sticks. Structural data were obtained from the X-ray crystal structure of MDM2-p53 complex (Protein Data Bank (PDB) id 1YCR). MDM2 is represented as surface, where carbon, oxygen, nitrogen, and sulfur are represented in green, red, blue, and yellow, respectively. Hydrogen-bonding interactions are depicted with a dashed blue line. Other types of interactions are represented as a dashed red line.

The 1.6 ̊ X-ray crystal structure of the small-molecule inhibitor of MDM2-p53 interaction 1 in complex with MDM2 (PDB id 4HG7 [50]) was selected for further molecular docking studies of the aminated xanthone derivatives 30-40 onto MDM2 protein, using the MDM2-p53 disruptors 1-4 as positive controls. In this work, AutoDock Vina [51] was the software chosen to predict docking conformations, as it has been described as being the best software in predicting crystallographic MDM2-p53 inhibitor poses (root-mean-square deviation (RMSD) $<1.0 \AA$ ) by redocking tests [52]. Docking scores for the most stable binding poses of xanthones 30-40 on MDM2 were determined using the AutoDock Vina software [51]. The predicted docking scores for known MDM2-p53 inhibitors (positive controls 1-4) ranged from -7.7 to $-8.0 \mathrm{kcal} \cdot \mathrm{mol}^{-1}$ (Table 1). The most stable binding conformation of the synthesized xanthones $\mathbf{3 0}-\mathbf{4 0}$ exhibited docking scores from -5.9 to $-7.4 \mathrm{kcal} \cdot \mathrm{mol}^{-1}$, therefore being in the same range of binding affinity as the positive controls (Table 1).

Amongst the tested compounds, the xanthone 37 was identified as the most active compound in the yeast-based screening assay. In addition, the predicted free energy values for the most stable binding pose of xanthone 37 were more negative than the majority of the remaining ligands. Therefore, the xanthone 37 was further analyzed in terms of docking poses and residues potentially involved in the interaction with MDM2. Figure 6A shows the most stable conformation of xanthone 37 as suggested by the docking protocol. The xanthone 37 was predicted to interact within the p53-binding site, mimicking the key hydrophobic residues of p53 when bound to MDM2 (docking score of $-7.3 \mathrm{kcal} \cdot \mathrm{mol}^{-1}$ ). Similarly to the binding mode of $\mathbf{1}$ within the p53-binding site (Figure 6B), no hydrogen-bonding interactions between the xanthone 37 and the MDM2 residues are predicted to be established. The $p$-fluorobenzylamino group of xanthone 37 occupies the Trp23 pocket and makes $\pi$-stacking interactions with Phe91 residue, amide- $\pi$ interactions with the Leu 57 and Gly58 residues, and CH- $\pi$ interactions with the Leu54, Leu57, Gly58, Ile61, Va193, and Ile99 residues. Interestingly, the docking conformation of $p$-fluorobenzylamino group and the $p$-chlorophenyl ring of $\mathbf{1}$ are identical and superimposable (Figure 6A,B). The methoxy groups of the xanthone scaffold are oriented to the Leu26 pocket and make $\mathrm{CH}-\mathrm{CH}$ interactions with the Leu54 residue. The adopted scaffold orientation of the xanthone 37 in the hydrophobic cleft where p53 is supposed to bind allows additional interactions to be formed, strengthening the binding of xanthone 37 to MDM2. For example, apart from the Gly58 residue of MDM2, the non-substituted aromatic ring of the xanthone scaffold is predicted to establish $\pi$-stacking 
interactions with the Phe55 residue, and amide- $\pi$ and $\mathrm{CH}-\pi$ interactions with the Gln59 residue. The establishment of additional interactions within the MDM2 protein that are not observed in the MDM2-p53 binding have been described for a considerable number of high-affinity p53-activating agents [17]. The visual inspection of the xanthone 37 also suggests that an enhancement of its binding affinity towards MDM2 protein can be achieved by molecular modifications in the xanthone scaffold of 37 in order to optimize its interaction with the amino acid residues surrounding the Phe19 pocket.

Table 1. Docking scores $\left(\mathrm{kcal} \cdot \mathrm{mol}^{-1}\right)$ of xanthones $\mathbf{3 0 - 4 0}$ and positive controls $\mathbf{1}-\mathbf{4}$ onto MDM2 target.

\begin{tabular}{|c|c|}
\hline \multicolumn{2}{|r|}{ Xanthones $30-40$} \\
\hline Ligands & Free Energy of the Ligand: MDM2 $\left(\mathrm{kcal} \cdot \mathrm{mol}^{-1}\right)$ \\
\hline 30 & -6.6 \\
\hline 31 & -6.2 \\
\hline 32 & -6.6 \\
\hline 33 & -5.9 \\
\hline 34 & -6.9 \\
\hline 35 & -7.2 \\
\hline 36 & -6.6 \\
\hline 37 & -7.3 \\
\hline 38 & -7.1 \\
\hline 39 & -7.3 \\
\hline 40 & -7.4 \\
\hline \multicolumn{2}{|r|}{ Inhibitors of MDM2-p53 Interaction } \\
\hline Ligands & Free Energy of the Ligand: MDM2 $\left(\mathrm{kcal}^{\prime} \mathrm{mol}^{-1}\right)$ \\
\hline 1 & -7.7 \\
\hline 2 & -8.0 \\
\hline 3 & -7.9 \\
\hline 4 & -8.0 \\
\hline
\end{tabular}
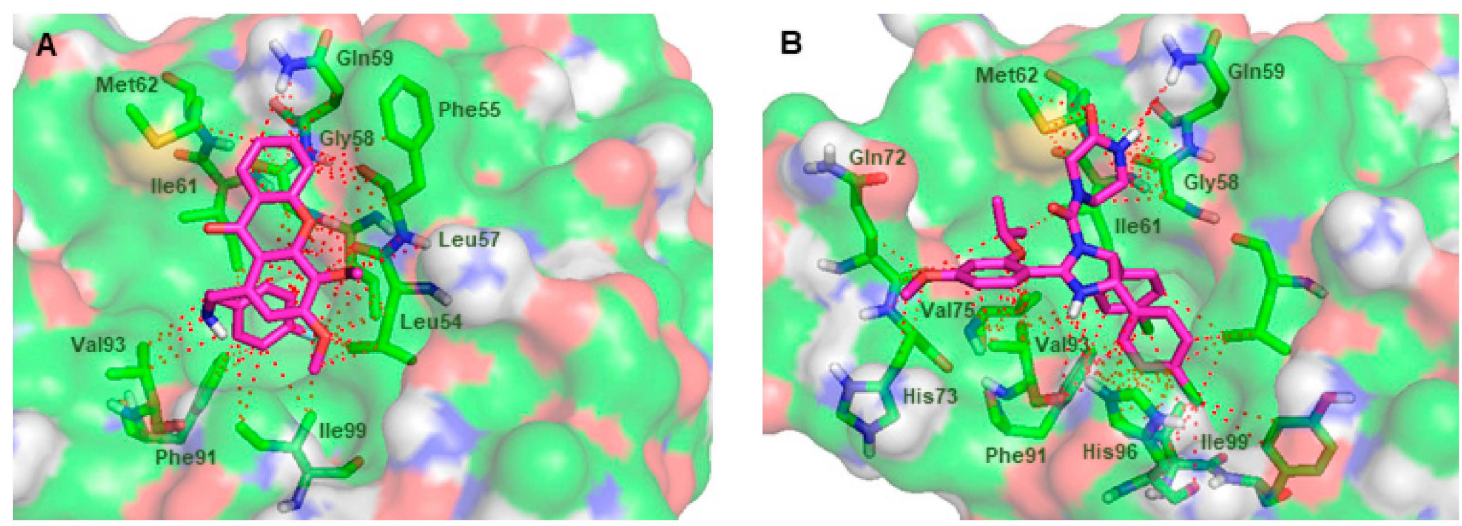

Figure 6. (A) Predicted binding pose of the xanthone 37 (purple sticks) in the binding site of MDM2. (B) MDM2 (transparent surface) in complex with the crystallographic nutlin-3A (1, purple sticks). MDM2 is represented as a transparent surface, where carbon, oxygen, nitrogen, and sulfur are represented in green, red, blue, and yellow, respectively. Small molecule-MDM2 interactions are depicted with a dashed red line. MDM2 residues involved in interactions with the ligands are represented as green sticks and labeled.

\section{Materials and Methods}

\subsection{Chemistry}

All reagents and solvents were purchased from Sigma Aldrich (Sigma-Aldrich Co. Ltd., Gillinghan, UK) and no further purification process was implemented. Solvents were evaporated using a rotary 
evaporator under reduced pressure, Buchi Waterchath B-480. Microwave (MW) reactions were performed using an Ethos MicroSYNTH 1600 Microwave Labstation from Milestone (Thermo Unicam, Portugal). The internal reaction temperature was controlled by a fiber optic probe sensor. All reactions were monitored by thin-layer chromatography (TLC) carried out on precoated plates with $0.2 \mathrm{~mm}$ of thickness using Merck silica gel $60\left(\mathrm{GF}_{254}\right)$ with appropriate mobile phases. Compounds $\mathbf{3 0}-\mathbf{4 0}$ were easily detectable at $254 \mathrm{~nm}$ or $365 \mathrm{~nm}$ and after revelation with a solution of ninhydrin in ethanol $3 \mathrm{mg} \cdot \mathrm{mL}^{-1}$ (activated by heat).

Flash column chromatography using silica gel 60 (0.040-0.063 mm, Merck, Darmstadt, Germany), flash cartridge chromatography (GraceResolv ${ }^{\circledR}$, Grace Company, Deerfield, IL, USA), and Discovery ${ }^{\circledR}$ DSC-SCX SPE cationic exchange cartridge (Grace Company, Deerfield, IL, USA) were used in the purification of the synthesized compounds. Melting points (m.p.) were measured in a Köfler microscope (Wagner and Munz, Munich, Germany) and are uncorrected. ${ }^{1} \mathrm{H}$ - and ${ }^{13} \mathrm{C}$-nuclear magnetic resonance (NMR) spectra were recorded at the University of Aveiro, Department of Chemistry in $\mathrm{CDCl}_{3}$ or DMSO- $d_{6}$ (Deutero $\mathrm{GmbH}$, Ely, UK) at room temperature on a Bruker Avance 300 spectrometer (300.13 MHz for ${ }^{1} \mathrm{H}$ and $75.47 \mathrm{MHz}$ for ${ }^{13} \mathrm{C}$, Bruker Biosciences Corporation, Billerica, MA, USA). Chemical shifts are expressed in $\delta(\mathrm{ppm})$ values relative to tetramethylsilane (TMS) as an internal reference. Coupling constants are reported in hertz $(\mathrm{Hz}) .{ }^{13} \mathrm{C}-\mathrm{NMR}$ assignments were made by bidimensional heteronuclear single quantum coherence (HSQC) and heteronuclear multiple bond correlation (HMBC) NMR experiments (long-range $C, \mathrm{H}$ coupling constants were optimized to $7 \mathrm{~Hz}$ ) or by comparison with the assignments of similar molecules. High-resolution mass spectroscopy (HRMS) spectra were measured on a Bruker FTMS APEX III mass spectrometer (Bruker Corporation, Billerica, MA, USA) and recorded as electrospray ionization (ESI) mode in Centro de Apoio Cientifico e Tecnolóxico á Investigación (CACTI, University of Vigo, Pontevedra, Spain). The following compounds were synthesized and purified by the described procedures.

\subsubsection{Synthesis of 3,4-dimethoxy-1-methyl-9H-xanthen-9-one (27)}

Xanthone 27 (9.34 g, 63\% yield) was synthesized from 1,2,3-trimethoxy-5-methylbenzene (25) and characterized according to the previously described procedure [42].

\subsubsection{Synthesis of 1-(dibromomethyl)-3,4-dimethoxy-9H-xanthen-9-one (28)}

A mixture of $27(2.52 \mathrm{~g}, 9.32 \mathrm{mmol}), \mathrm{N}$-bromosuccinimide $(3.32 \mathrm{~g}, 18.7 \mathrm{mmol})$, and dibenzoyl peroxide $(0.68 \mathrm{~g}, 2.8 \mathrm{mmol})$ in carbon tetrachloride $(25 \mathrm{~mL})$ was refluxed $\left(85^{\circ} \mathrm{C}\right)$ for $2 \mathrm{~h}$. The reaction was monitored using $n$-hexane/ethyl acetate in a proportion of $8: 2$. Once the reaction was completed, the resulting orange suspension was cooled at $0{ }^{\circ} \mathrm{C}$ and stirred for $30 \mathrm{~min}$ in an ice bath. The solid was filtered and washed with cold carbon tetrachloride. The filtrate was evaporated under reduced pressure and further purified by flash column chromatography $\left(\mathrm{SiO}_{2}, n\right.$-hexane/ethyl acetate in gradient) to obtain the 28 as a white powder.

For 1-(dibromomethyl)-3,4-dimethoxy-9H-xanthen-9-one (28): White powder (3.14 g, 80\% yield); melting point (m.p.) $125-127{ }^{\circ} \mathrm{C} .{ }^{1} \mathrm{H}-\mathrm{NMR}\left(\mathrm{CDCl}_{3}, 300.13 \mathrm{MHz}\right): \delta=8.91(1 \mathrm{H}, \mathrm{s}, \mathrm{H}-1), 8.30(1 \mathrm{H}, \mathrm{dd}$, $J=8.0$ and $1.6 \mathrm{~Hz}, \mathrm{H}-8), 7.77(1 \mathrm{H}, \mathrm{s}, \mathrm{H}-2), 7.73(1 \mathrm{H}, \mathrm{ddd}, J=8.4,7.0$, and $1.6 \mathrm{~Hz}, \mathrm{H}-6), 7.54(1 \mathrm{H}, \mathrm{d}$, $J=8.4 \mathrm{~Hz}, \mathrm{H}-5), 7.39(1 \mathrm{H}, \mathrm{ddd}, J=7.5, \mathrm{H}-7), 4.11\left(3 \mathrm{H}, \mathrm{s}, 4-\mathrm{OCH}_{3}\right), 4.05\left(3 \mathrm{H}, \mathrm{s}, 3-\mathrm{OCH}_{3}\right) \mathrm{ppm} ;{ }^{13} \mathrm{C}-\mathrm{NMR}$ $\left(\mathrm{CDCl}_{3}, 75.47 \mathrm{MHz}\right): \delta=177.8$ (C-9), 156.5 (C-3), 155.0 (C-10a), 150.4 (C-4a), 139.5 (C-4), 137.6 (C-1), 135.0 (C-6), 126.9 (C-8), 124.3 (C-7), 122.0 (C-8a), 117.6 (C-5), 111.9 (C-2), 110.8 (C-9a), $61.9\left(3-\mathrm{OCH}_{3}\right)$, $56.6\left(4-\mathrm{OCH}_{3}\right), 39.2\left(\mathrm{C}-1^{\prime}\right)$ ppm. HRMS $\left(\mathrm{ESI}^{+}\right): \mathrm{m} / z\left[\mathrm{C}_{16} \mathrm{H}_{12} \mathrm{Br}_{2} \mathrm{O}_{5}+\mathrm{H}\right]^{+}$calcd. for $\left[\mathrm{C}_{16} \mathrm{H}_{13} \mathrm{Br}_{2} \mathrm{O}_{5}\right]$ : 426.91751; found: 426.91709 .

\subsubsection{Synthesis of 3,4-dimethoxy-9-oxo-9H-xanthene-1-carbaldehyde (5)}

Xanthone 28 (3.14 g, $7.34 \mathrm{mmol})$ was added to a solution of 1-butyl-3-methylimidazolium tetrafluoroborate and water $(6 \mathrm{~mL}, 5: 1)$. The mixture was heated at $100{ }^{\circ} \mathrm{C}$ with stirring for $2.5 \mathrm{~h}$. The reaction was monitored using $n$-hexane/ethyl acetate in a proportion of 7:3. After completion of the 
reaction, the resulting suspension was cooled at room temperature, diluted with water $(10 \mathrm{~mL})$, and extracted with ethyl acetate $(5 \times 100 \mathrm{~mL})$. The combined organic layers were dried over anhydrous sodium sulfate, and after filtration of the solution, the solvent was evaporated under reduced pressure. The crude product was then purified by flash column chromatography $\left(\mathrm{SiO}_{2}, n\right.$-hexane/ethyl acetate in gradient). A light yellow powder corresponding to 5 was obtained.

For 3,4-dimethoxy-9-oxo-9H-xanthene-1-carbaldehyde (5): Light yellow powder (1.33 g, 64\% yield); m.p. $>330{ }^{\circ} \mathrm{C} .{ }^{1} \mathrm{H}-\mathrm{NMR}\left(\mathrm{CDCl}_{3}, 300.13 \mathrm{MHz}\right): \delta=11.21\left(1 \mathrm{H}, \mathrm{s}, \mathrm{H}-1^{\prime}\right), 8.31(1 \mathrm{H}, \mathrm{dd}, J=8.0$ and $1.7 \mathrm{~Hz}, \mathrm{H}-8), 7.77(1 \mathrm{H}, \mathrm{ddd}, J=8.5,7.0$, and $1.7 \mathrm{~Hz}, \mathrm{H}-6), 7.60(1 \mathrm{H}, \mathrm{dd}, J=8.5$ and $0.8 \mathrm{~Hz}, \mathrm{H}-5), 7.56(1 \mathrm{H}$, $\mathrm{s}, \mathrm{H}-2), 7.43(1 \mathrm{H}, \mathrm{ddd}, J=8.0,7.0$, and $0.8 \mathrm{~Hz}, \mathrm{H}-7), 4.11\left(3 \mathrm{H}, \mathrm{s}, 4-\mathrm{OCH}_{3}\right), 4.07\left(3 \mathrm{H}, \mathrm{s}, 3-\mathrm{OCH}_{3}\right) \mathrm{ppm}$; ${ }^{13} \mathrm{C}-\mathrm{NMR}\left(\mathrm{CDCl}_{3}, 75.47 \mathrm{MHz}\right): \delta=192.8\left(\mathrm{C}-1^{\prime}\right), 177.9$ (C-9), 156.3 (C-3), 155.5 (C-10a), 150.9 (C-4a), 140.7 (C-4), 135.1 (C-6), 133.5 (C-1), 126.7 (C-8), 124.5 (C-7), 121.9 (C-8a), 117.8 (C-5), 116.1 (C-9a), 108.5 $(\mathrm{C}-2), 61.8\left(4-\mathrm{OCH}_{3}\right), 56.6\left(3-\mathrm{OCH}_{3}\right)$ ppm. HRMS $\left(\mathrm{ESI}^{+}\right): \mathrm{m} / z\left[\mathrm{C}_{16} \mathrm{H}_{12} \mathrm{O}_{5}+\mathrm{H}\right]^{+}$calcd. for $\left[\mathrm{C}_{16} \mathrm{H}_{13} \mathrm{O}_{5}\right]$ : 285.07575; found: 285.07598; [ $\left.\mathrm{C}_{16} \mathrm{H}_{12} \mathrm{O}_{5}+\mathrm{Na}\right]^{-}$calcd. for $\left[\mathrm{C}_{16} \mathrm{H}_{12} \mathrm{NaO}_{5}\right]$ : 307.05769; found 307.05750.

\subsubsection{Synthesis of 1-(hydroxymethyl)-3,4-dimethoxy-9H-xanthen-9-one (29)}

Xanthone 29 (52 mg, 52\% yield) was synthesized from xanthone 5 and characterized according to the previously described procedure [36].

\subsubsection{General Procedure for the Synthesis of Xanthones (30-40)}

Xanthone 5 (40 mg, $0.141 \mathrm{mmol})$ was dissolved in tetrahydrofuran $(3 \mathrm{~mL})$ and the appropriate amine precursors 9-19 $(0.197 \mathrm{mmol})$ were added to the solution under $\mathrm{N}_{2}$ gas. After the addition of a 4.0 equimolar quantity of sodium triacetoxyborohydride $(119 \mathrm{mg}, 0.563 \mathrm{mmol})$, the resulting mixture was stirred at room temperature for $30 \mathrm{~min}$. Subsequently, a 3.0 equimolar quantity of acetic acid $(24 \mu \mathrm{L}$ $0.423 \mathrm{mmol}$ ) was added to the solution, The reaction was carried out at room temperature for $12 \mathrm{~h}$ under $\mathrm{N}_{2}$ gas. For monitoring the synthesis of xanthones $\mathbf{3 0 - 4 0}$ by TLC, two chromatographic systems were employed: (i) $n$-hexane/ethyl acetate (7:3) and methanol/triethylamine (10:0.1) for xanthones 30-36; (ii) $n$-hexane/ethyl acetate (7:3) and chloroform/acetone/triethylamine (5:5:0.1) for xanthones 37-40. Once completed of the reaction, three distinct work-up approaches were employed.

(a) For xanthones 30-32: the solvent was evaporated under reduced pressure and the resulting crude product was basified with sodium hydroxide $(10 \mathrm{~mL}, 5 \%, \mathrm{~m} / \mathrm{v})$ and extracted with chloroform $(3 \times 10 \mathrm{~mL})$. The combined organic phases were then acidified and extracted with hydrochloric acid $5 \mathrm{M}(3 \times 30 \mathrm{~mL})$. Afterwards, the aqueous phases were gathered and then basified with sodium hydroxide $(100 \mathrm{~mL}, 20 \%, \mathrm{~m} / \mathrm{v})$. The crude product was extracted successively with chloroform $(3 \times$ $100 \mathrm{~mL}$ ). The organic layers were gathered and dried over anhydrous sodium sulfate. After filtration, the solution was concentrated under reduced pressure, and the resulting crude product was purified by flash cartridge chromatography $\left(\mathrm{SiO}_{2}\right.$, chloroform/acetone/ammonium hydroxide, 90:10:1) to afford the xanthones 30,31 , and 32 as pure compounds.

For 3,4-dimethoxy-1-(((2-morpholinoethyl)amino)methyl)-9H-xanthen-9-one (30): Green powder (35 mg, 62\% yield); m.p. $125-126{ }^{\circ} \mathrm{C} .{ }^{1} \mathrm{H}-\mathrm{NMR}\left(\mathrm{CDCl}_{3}, 300.13 \mathrm{MHz}\right): \delta=8.25(1 \mathrm{H}, \mathrm{dd}, J=8.0$ and $1.6 \mathrm{~Hz}, \mathrm{H}-8), 7.72(1 \mathrm{H}, \mathrm{ddd}, J=8.1,7.0$, and $1.6 \mathrm{~Hz}, \mathrm{H}-6), 7.57(1 \mathrm{H}, \mathrm{dd}, J=8.4$ and $0.8 \mathrm{~Hz}, \mathrm{H}-5), 7.38(1 \mathrm{H}$, $\mathrm{ddd}, J=8.0,7.1$, and $0.9 \mathrm{~Hz}, \mathrm{H}-7), 7.09(1 \mathrm{H}, \mathrm{s}, \mathrm{H}-2), 4.34\left(2 \mathrm{H}, \mathrm{s}, \mathrm{H}-1^{\prime}\right) ; 4.04\left(3 \mathrm{H}, \mathrm{s}, 4-\mathrm{OCH}_{3}\right), 4.01(3 \mathrm{H}$, $\left.\mathrm{s}, 3-\mathrm{OCH}_{3}\right), 3.66\left(4 \mathrm{H}, \mathrm{t}, J=4.6 \mathrm{~Hz}, \mathrm{H}-5^{\prime}\right), 2.90\left(2 \mathrm{H}, \mathrm{t}, J=6.1 \mathrm{~Hz}, \mathrm{H}-2^{\prime}\right), 2.60\left(2 \mathrm{H}, \mathrm{t}, J=6.1 \mathrm{~Hz}, \mathrm{H}-3^{\prime}\right)$, $2.47\left(4 \mathrm{H}, \mathrm{t}, J=4.3 \mathrm{~Hz}, \mathrm{H}-4^{\prime}\right) \mathrm{ppm} ;{ }^{13} \mathrm{C}-\mathrm{NMR}\left(\mathrm{CDCl}_{3}, 75.47 \mathrm{MHz}\right): \delta=178.0(\mathrm{C}-9), 156.5(\mathrm{C}-3), 155.3$ (C-10a), 152.1 (C-4a), 137.0 (C-1), 136.0 (C-4), 134.6 (C-6), 126.5 (C-8), 124.1 (C-7), 122.1 (C-8a), 117.7 (C-5), $114.6(\mathrm{C}-9 \mathrm{a}), 111.6(\mathrm{C}-2), 67.0\left(\mathrm{C}-5^{\prime}\right), 61.5\left(4-\mathrm{OCH}_{3}\right), 57.4\left(\mathrm{C}-2^{\prime}\right), 56.4\left(3-\mathrm{OCH}_{3}\right), 53.7\left(\mathrm{C}-1^{\prime}\right), 53.5$ $\left(\mathrm{C}-4^{\prime}\right), 45.3\left(\mathrm{C}-3^{\prime}\right)$ ppm. HRMS $\left(\mathrm{ESI}^{+}\right): \mathrm{m} / z\left[\mathrm{C}_{22} \mathrm{H}_{26} \mathrm{~N}_{2} \mathrm{O}_{5}+\mathrm{H}\right]^{+}$calcd. for $\left[\mathrm{C}_{22} \mathrm{H}_{27} \mathrm{~N}_{2} \mathrm{O}_{5}\right]$ : 399.19145 ; found: 399.19060.

For 1-(((3-(dimethylamino)propyl)(methyl)amino)methyl)-3,4-dimethoxy-9H-xanthen-9-one (31): White powder $\left(35 \mathrm{mg}, 65 \%\right.$ yield); m.p. $84-85{ }^{\circ} \mathrm{C} .{ }^{1} \mathrm{H}-\mathrm{NMR}\left(\mathrm{CDCl}_{3}, 300.13 \mathrm{MHz}\right): \delta=8.25(1 \mathrm{H}, \mathrm{dd}$, $J=8.0$ and $1.6 \mathrm{~Hz}, \mathrm{H}-8), 7.69(1 \mathrm{H}, \mathrm{ddd}, J=8.5,7.0$, and $1.6 \mathrm{~Hz}, \mathrm{H}-6), 7.54(1 \mathrm{H}, \mathrm{dd}, J=7.4$ and $0.7, \mathrm{H}-5)$, 
$7.53(1 \mathrm{H}, \mathrm{s}, \mathrm{H}-2), 7.35(1 \mathrm{H}, \mathrm{ddd}, J=8.0,7.1$, and $1.0 \mathrm{~Hz}, \mathrm{H}-7), 4.36\left(2 \mathrm{H}, \mathrm{s}, \mathrm{H}-1^{\prime}\right) ; 4.05\left(3 \mathrm{H}, \mathrm{s}, 4-\mathrm{OCH}_{3}\right)$, $4.02\left(3 \mathrm{H}, \mathrm{s}, 3-\mathrm{OCH}_{3}\right), 2.65\left(2 \mathrm{H}, \mathrm{t}, J=7.2 \mathrm{~Hz}, \mathrm{H}-3^{\prime}\right), 2.44\left(2 \mathrm{H}, \mathrm{t}, J=7.5 \mathrm{~Hz}, \mathrm{H}-5^{\prime}\right), 2.39\left(3 \mathrm{H}, \mathrm{s}, \mathrm{H}-2^{\prime}\right)$, $2.28\left(6 \mathrm{H}, \mathrm{s}, \mathrm{H}-6^{\prime}\right), 1.82\left(2 \mathrm{H}, \mathrm{m}, J=7.3 \mathrm{~Hz}, \mathrm{H}-4^{\prime}\right) \mathrm{ppm} ;{ }^{13} \mathrm{C}-\mathrm{NMR}\left(\mathrm{CDCl}_{3}, 75.47 \mathrm{MHz}\right): \delta=178.1(\mathrm{C}-9)$, 156.6 (C-3), 155.2 (C-10a), 151.9 (C-4a), 135.2 (C-1), 135.0 (C-4), 134.2 (C-6), 126.6 (C-8), 123.9 (C-7), 122.4 (C-8a), 117.6 (C-5), 114.5 (C-9a), $109.0(\mathrm{C}-2), 61.5\left(4-\mathrm{OCH}_{3}\right), 60.1\left(\mathrm{C}-1^{\prime}\right), 57.8\left(\mathrm{C}-5^{\prime}\right), 56.4\left(3-\mathrm{OCH}_{3}\right)$, $56.1\left(\mathrm{C}-3^{\prime}\right), 45.3\left(\mathrm{C}-6^{\prime}\right), 42.5\left(\mathrm{C}-2^{\prime}\right), 25.3\left(\mathrm{C}-4^{\prime}\right)$ ppm. HRMS $\left(\mathrm{ESI}^{+}\right): \mathrm{m} / z\left[\mathrm{C}_{22} \mathrm{H}_{28} \mathrm{~N}_{2} \mathrm{O}_{4}+\mathrm{H}\right]^{+}$calcd. for $\left[\mathrm{C}_{22} \mathrm{H}_{29} \mathrm{~N}_{2} \mathrm{O}_{4}\right]$ : 385.21218; found: 385.21139 .

For 1-((4-(2-hydroxyethyl)piperazin-1-yl)methyl)-3,4-dimethoxy-9H-xanthen-9-one (32): Yellow powder (40 mg, $71 \%$ yield); m.p. $129-130{ }^{\circ} \mathrm{C} .{ }^{1} \mathrm{H}-\mathrm{NMR}\left(\mathrm{CDCl}_{3}, 300.13 \mathrm{MHz}\right): \delta=8.25(1 \mathrm{H}, \mathrm{dd}, J=8.0$ and $1.6 \mathrm{~Hz}, \mathrm{H}-8), 7.68(1 \mathrm{H}, \mathrm{ddd}, J=8.5,7.0$, and $1.6 \mathrm{~Hz}, \mathrm{H}-6), 7.53(1 \mathrm{H}, \mathrm{dd}, J=8.4$ and $0.7 \mathrm{~Hz}, \mathrm{H}-5), 7.48$ $(1 \mathrm{H}, \mathrm{s}, \mathrm{H}-2), 7.35(1 \mathrm{H}, \mathrm{ddd}, J=8.0,7.1$, and $1.0 \mathrm{~Hz}, \mathrm{H}-7), 4.32\left(2 \mathrm{H}, \mathrm{s}, \mathrm{H}-\mathrm{1}^{\prime}\right), 4.03\left(3 \mathrm{H}, \mathrm{s}, 4-\mathrm{OCH}_{3}\right), 4.01$ $\left(3 \mathrm{H}, \mathrm{s}, 3-\mathrm{OCH}_{3}\right), 3.63(2 \mathrm{H}, \mathrm{t}, J=5.4 \mathrm{~Hz}), 2.58(2 \mathrm{H}, \mathrm{t}, J=5.4 \mathrm{~Hz}) \mathrm{ppm} ;{ }^{13} \mathrm{C}-\mathrm{NMR}\left(\mathrm{CDCl}_{3}, 75.47 \mathrm{MHz}\right): \delta$ = 178.1 (C-9), 156.5 (C-3), 155.2 (C-10a), 152.0 (C-4a), 138.8 (C-1), 134.8 (C-4), 134.2 (C-6), 126.6 (C-8), 123.9 (C-7), 122.5 (C-8a), 117.5 (C-5), 114.6 (C-9a), $108.2(\mathrm{C}-2), 61.5\left(4-\mathrm{OCH}_{3}\right), 60.2\left(\mathrm{C}-1^{\prime}\right), 59.3\left(\mathrm{C}-5^{\prime}\right)$, $57.7\left(\mathrm{C}-4^{\prime}\right), 56.2\left(3-\mathrm{OCH}_{3}\right), 53.5\left(\mathrm{C}-3^{\prime}\right), 53.2\left(\mathrm{C}-2^{\prime}\right)$ ppm. HRMS $\left(\mathrm{ESI}^{+}\right): m / z\left[\mathrm{C}_{22} \mathrm{H}_{26} \mathrm{~N}_{2} \mathrm{O}_{5}+\mathrm{H}\right]^{+}$calcd. for $\left[\mathrm{C}_{22} \mathrm{H}_{27} \mathrm{~N}_{2} \mathrm{O}_{5}\right]$ : 399.19145; found: 399.19059 .

(b) For xanthones 33-36: the solvent was evaporated under reduced pressure and the crude product was extracted with chloroform $(3 \times 10 \mathrm{~mL})$. The organic phases were gathered, dried over anhydrous sodium sulfate, and after filtration, the resulting solution was concentrated under reduced pressure. Then, a solid phase extraction using a cation exchange cartridge Discovery ${ }^{\circledR}$ DSC-SCX was applied to further purify the crude product. Initially, an activation of the cartridge with methanol $(100 \mathrm{~mL})$ was carried out followed by loading the cartridge with the sample. Then, the elution was performed with the following solvents/solutions: (i) dichloromethane/methanol (5:5), (ii) methanol, and (iii) ammonium hydroxide/methanol $(2 \%, v / v)$. The fractions obtained from the elution with ammonium hydroxide/methanol $(2 \%, v / v)$ were gathered and the solvent was evaporated under reduced pressure. A flash cartridge chromatography with chloroform/acetone/ammonium hydroxide (90:10:1) was also performed to obtain the xanthones $33,34,35$, and 36 as pure compounds.

For 1-((2-(diethylamino)ethyl)amino)methyl)-3,4-dimethoxy-9H-xanthen-9-one (33): Green powder $\left(28 \mathrm{mg}\right.$, 52\% yield); m.p. $68-69{ }^{\circ} \mathrm{C} .{ }^{1} \mathrm{H}-\mathrm{NMR}\left(\mathrm{CDCl}_{3}, 300.13 \mathrm{MHz}\right): \delta=8.27(1 \mathrm{H}, \mathrm{dd}, J$ $=8.0$ and $1.4 \mathrm{~Hz}, \mathrm{H}-8), 7.71(1 \mathrm{H}, \mathrm{ddd}, J=8.5,7.0$, and $1.6 \mathrm{~Hz}, \mathrm{H}-6), 7.56(1 \mathrm{H}, \mathrm{dd}, J=8.4$ and $0.7 \mathrm{~Hz}, \mathrm{H}-5)$, $7.37(1 \mathrm{H}, \mathrm{ddd}, J=8.0,7.1$, and $1.0 \mathrm{~Hz}, \mathrm{H}-7), 7.14(1 \mathrm{H}, \mathrm{s}, \mathrm{H}-2), 4.39\left(2 \mathrm{H}, \mathrm{s}, \mathrm{H}-1^{\prime}\right) ; 4.05\left(3 \mathrm{H}, \mathrm{s}, 4-\mathrm{OCH}_{3}\right)$, $4.01\left(3 \mathrm{H}, \mathrm{s}, 3-\mathrm{OCH}_{3}\right), 2.87\left(2 \mathrm{H}, \mathrm{t}, J=6.4 \mathrm{~Hz}, \mathrm{H}-2^{\prime}\right), 2.68\left(2 \mathrm{H}, \mathrm{t}, J=6.4 \mathrm{~Hz}, \mathrm{H}-3^{\prime}\right), 2.55(4 \mathrm{H}, \mathrm{m}, J=7.1$ $\left.\mathrm{Hz}, \mathrm{H}-4^{\prime}\right), 1.01\left(6 \mathrm{H}, \mathrm{t}, J=7.1 \mathrm{~Hz}, \mathrm{H}-5^{\prime}\right) \mathrm{ppm} ;{ }^{13} \mathrm{C}-\mathrm{NMR}\left(\mathrm{CDCl}_{3}, 75.47 \mathrm{MHz}\right): \delta=178.1(\mathrm{C}-9), 156.5$ (C-3), 155.3 (C-10a), 152.1 (C-4a), 137.4 (C-1), 135.8 (C-4), 134.5 (C-6), 126.6 (C-8), 124.0 (C-7), 122.2 (C-8a), 117.7 (C-5), 114.5 (C-9a), $111.1(\mathrm{C}-2), 61.5\left(4-\mathrm{OCH}_{3}\right), 56.4\left(3-\mathrm{OCH}_{3}\right), 53.4\left(\mathrm{C}-3^{\prime}\right), 52.4\left(\mathrm{C}-1^{\prime}\right), 46.9$ $\left(\mathrm{C}-4^{\prime}\right), 46.8\left(\mathrm{C}-2^{\prime}\right), 11.6\left(\mathrm{C}-5^{\prime}\right)$ ppm. HRMS $\left(\mathrm{ESI}^{+}\right): \mathrm{m} / z\left[\mathrm{C}_{22} \mathrm{H}_{28} \mathrm{~N}_{2} \mathrm{O}_{4}+\mathrm{H}\right]^{+}$calcd. for $\left[\mathrm{C}_{22} \mathrm{H}_{29} \mathrm{~N}_{2} \mathrm{O}_{4}\right]$ : 385.21218; found: 385.21150 .

For 4-((3,4-dimethoxy-9-oxo-9H-xanthen-1-yl)methyl)piperazin-2-one (34): Orange powder (20 mg, 39\% yield); m.p. $245-247{ }^{\circ} \mathrm{C} .{ }^{1} \mathrm{H}-\mathrm{NMR}$ (DMSO- $\left.d_{6}, 300.13 \mathrm{MHz}\right): \delta=8.13(1 \mathrm{H}, \mathrm{dd}, J=$ 8.0 and $1.5 \mathrm{~Hz}, \mathrm{H}-8), 7.82(1 \mathrm{H}, \mathrm{ddd}, J=8.5,7.0$, and $1.6 \mathrm{~Hz}, \mathrm{H}-6), 7.65(1 \mathrm{H}, \mathrm{dd}, J=8.4$ and $0.6, \mathrm{H}-5)$, $7.45(1 \mathrm{H}, \mathrm{ddd}, J=8.0,7.1$, and $1.0 \mathrm{~Hz}, \mathrm{H}-7), 7.36(1 \mathrm{H}, \mathrm{s}, \mathrm{H}-2), 4.24\left(2 \mathrm{H}, \mathrm{s}, \mathrm{H}-1^{\prime}\right) ; 3.98\left(3 \mathrm{H}, \mathrm{s}, 4-\mathrm{OCH}_{3}\right)$, $3.90\left(3 \mathrm{H}, \mathrm{s}, 3-\mathrm{OCH}_{3}\right), 3.20\left(2 \mathrm{H}, \mathrm{t}, J=5.3 \mathrm{~Hz}, \mathrm{H}-5^{\prime}\right), 3.13\left(2 \mathrm{H}, \mathrm{s}, \mathrm{H}-2^{\prime}\right), 2.66\left(2 \mathrm{H}, \mathrm{t}, J=5.3 \mathrm{~Hz}, \mathrm{H}-4^{\prime}\right) \mathrm{ppm}$; ${ }^{13} \mathrm{C}-\mathrm{NMR}\left(\mathrm{DMSO}-d_{6}, 75.47 \mathrm{MHz}\right): \delta=176.7$ (C-9), 168.0 (C-3'), 156.2 (C-3), 154.6 (C-10a), 151.8 (C-4a), 136.9 (C-1), 135.0 (C-4), 134.7 (C-6), 126.1 (C-8), 124.3 (C-7), 121.8 (C-8a), 117.7 (C-5), 113.7 (C-9a), 109.2 (C-2), $60.9\left(4-\mathrm{OCH}_{3}\right), 58.5\left(\mathrm{C}-1^{\prime}\right), 57.2\left(\mathrm{C}-5^{\prime}\right), 56.3\left(3-\mathrm{OCH}_{3}\right), 48.7\left(\mathrm{C}-2^{\prime}\right), 30.7\left(\mathrm{C}-4^{\prime}\right)$ ppm. HRMS $\left(\mathrm{ESI}^{+}\right)$: $\mathrm{m} / \mathrm{z}\left[\mathrm{C}_{20} \mathrm{H}_{20} \mathrm{~N}_{2} \mathrm{O}_{5}+\mathrm{H}\right]^{+}$calcd. for $\left[\mathrm{C}_{20} \mathrm{H}_{21} \mathrm{~N}_{2} \mathrm{O}_{5}\right]$ : 369.14450; found: 369.14369 .

For 1-((5-amino-3,4-dihydroisoquinolin-2(1H)-yl)methyl)-3,4-dimethoxy-9H-xanthen-9-one (35): White powder (23 mg, 39\% yield); m.p. $171-172{ }^{\circ} \mathrm{C} .{ }^{1} \mathrm{H}-\mathrm{NMR}\left(\mathrm{CDCl}_{3}, 300.13 \mathrm{MHz}\right): \delta=8.26(1 \mathrm{H}$, dd, $J=8.0$ and $1.4 \mathrm{~Hz}, \mathrm{H}-8), 7.69(1 \mathrm{H}, \mathrm{ddd}, J=8.5,7.0$, and $1.6 \mathrm{~Hz}, \mathrm{H}-6), 7.57(1 \mathrm{H}, \mathrm{s}, \mathrm{H}-2), 7.54(1 \mathrm{H}, \mathrm{dd}, J=$ 8.4 and $0.7 \mathrm{~Hz}, \mathrm{H}-5), 7.35(1 \mathrm{H}, \mathrm{ddd}, J=8.0,7.1$, and $1.0 \mathrm{~Hz}, \mathrm{H}-7), 6.99\left(1 \mathrm{H}, \mathrm{t}, J=7.7 \mathrm{~Hz}, \mathrm{H}-7^{\prime}\right), 6.57$ 
$\left(1 \mathrm{H}, \mathrm{d}, J=7.8 \mathrm{~Hz}, \mathrm{H}-6^{\prime}\right), 6.53\left(1 \mathrm{H}, \mathrm{d}, J=7.6 \mathrm{~Hz}, \mathrm{H}-8^{\prime}\right), 4.48\left(2 \mathrm{H}, \mathrm{s}, \mathrm{H}-1^{\prime}\right) ; 4.02\left(3 \mathrm{H}, \mathrm{s}, 4-\mathrm{OCH}_{3}\right), 3.97$ $\left(3 \mathrm{H}, \mathrm{s}, 3-\mathrm{OCH}_{3}\right), 3.81\left(2 \mathrm{H}, \mathrm{s}, \mathrm{H}-10^{\prime}\right), 2.93\left(2 \mathrm{H}, \mathrm{t}, J=5.9 \mathrm{~Hz}, \mathrm{H}-2^{\prime}\right), 2.66\left(2 \mathrm{H}, \mathrm{t}, J=5.9 \mathrm{~Hz}, \mathrm{H}-3^{\prime}\right)$ ppm; ${ }^{13} \mathrm{C}-\mathrm{NMR}\left(\mathrm{CDCl}_{3}, 75.47 \mathrm{MHz}\right): \delta=178.2$ (C-9), 156.7 (C-3), 155.2 (C-10a), 151.9 (C-4a), 144.1 (C-5'), 139.3 (C-1), 136.3 (C-9'), 134.8 (C-4), 134.2 (C-6), 126.6 (C-8), 126.4 (C-7'), 123.8 (C-7), 122.5 (C-8a), 119.5 $\left(\mathrm{C}-4^{\prime}\right), 117.6(\mathrm{C}-5), 117.1\left(\mathrm{C}-8^{\prime}\right), 114.5(\mathrm{C}-9 \mathrm{a}), 112.7\left(\mathrm{C}-6^{\prime}\right), 108.0(\mathrm{C}-2), 61.5\left(4-\mathrm{OCH}_{3}\right), 60.1\left(\mathrm{C}-1^{\prime}\right), 56.7$ $\left(\mathrm{C}-10^{\prime}\right), 56.3\left(3-\mathrm{OCH}_{3}\right), 51.0\left(\mathrm{C}-2^{\prime}\right), 24.9\left(\mathrm{C}-3^{\prime}\right)$ ppm. HRMS $\left(\mathrm{ESI}^{+}\right): \mathrm{m} / z\left[\mathrm{C}_{25} \mathrm{H}_{24} \mathrm{~N}_{2} \mathrm{O}_{4}+\mathrm{H}\right]^{+}$calcd. for $\left[\mathrm{C}_{25} \mathrm{H}_{25} \mathrm{~N}_{2} \mathrm{O}_{4}\right]$ : 417.18088; found: 417.18018 .

For 3,4-dimethoxy-1-(piperidin-1-ylmethyl)-9H-xanthen-9-one (36): Yellow powder (31 mg, 62\% yield); m.p. 108-109 ${ }^{\circ} \mathrm{C} .{ }^{1} \mathrm{H}-\mathrm{NMR}\left(\mathrm{CDCl}_{3}, 300.13 \mathrm{MHz}\right): \delta=8.25(1 \mathrm{H}, \mathrm{dd}, J=8.0$ and $1.6 \mathrm{~Hz}, \mathrm{H}-8), 7.66$ $(1 \mathrm{H}, \mathrm{ddd}, J=8.5,8.0$, and $1.6 \mathrm{~Hz}, \mathrm{H}-6), 7.56(1 \mathrm{H}, \mathrm{s}, \mathrm{H}-2), 7.52(1 \mathrm{H}, \mathrm{dd}, J=8.3$ and $0.7 \mathrm{~Hz}, \mathrm{H}-5), 7.33(1 \mathrm{H}$, ddd, $J=7.9,7.1$, and $0.9 \mathrm{~Hz}, \mathrm{H}-7), 4.26\left(2 \mathrm{H}, \mathrm{s}, \mathrm{H}-1^{\prime}\right) ; 4.03\left(3 \mathrm{H}, \mathrm{s}, 4-\mathrm{OCH}_{3}\right), 4.01\left(3 \mathrm{H}, \mathrm{s}, 3-\mathrm{OCH}_{3}\right), 2.57(4 \mathrm{H}$, $\left.\mathrm{t}, J=4.6 \mathrm{~Hz}, \mathrm{H}-2^{\prime}\right), 1.65\left(4 \mathrm{H}, \mathrm{m}, J=5.5 \mathrm{~Hz}, \mathrm{H}-3^{\prime}\right), 1,50\left(2 \mathrm{H}, \mathrm{m}, J=5.5 \mathrm{~Hz}, \mathrm{H}-4^{\prime}\right) \mathrm{ppm} ;{ }^{13} \mathrm{C}-\mathrm{NMR}\left(\mathrm{CDCl}_{3}\right.$, $75.47 \mathrm{MHz}$ ) ppm: $\delta=177.5$ (C-9), 156.1 (C-3), 154.7 (C-10a), 151.3 (C-4a), 138.9 (C-4), 134.2 (C-1), 133.8 (C-6), 126.0 (C-8), 123.3 (C-7), 121.9 (C-8a), 117.1 (C-5), 113.9 (C-9a), 107.8 (C-2), $60.8\left(4-\mathrm{OCH}_{3}\right), 56.1$ $\left(3-\mathrm{OCH}_{3}\right), 55.7\left(\mathrm{C}-2^{\prime}\right), 54.3\left(\mathrm{C}-1^{\prime}\right), 25.7\left(\mathrm{C}-3^{\prime}\right), 23.8\left(\mathrm{C}-4^{\prime}\right)$ ppm. HRMS $\left(\mathrm{ESI}^{+}\right): \mathrm{m} / z\left[\mathrm{C}_{21} \mathrm{H}_{23} \mathrm{NO}_{4}+\mathrm{H}\right]^{+}$ calcd. for $\left[\mathrm{C}_{21} \mathrm{H}_{24} \mathrm{NO}_{4}\right]$ : 354.16998; found: 354.16939 .

(c) For xanthones 37-40: the solvent was evaporated under reduced pressure and the resulting crude product was basified with sodium hydroxide $(10 \mathrm{~mL}, 5 \%, \mathrm{~m} / \mathrm{v})$ and extracted with chloroform $(3 \times 10 \mathrm{~mL})$. The combined organic phases were then acidified and extracted with hydrochloric acid $5 \mathrm{M}(3 \times 30 \mathrm{~mL})$. The resulting organic phase was dried over anhydrous sodium sulfate and, after filtration, the solution was concentrated under reduced pressure. Then, a solid phase extraction using a cation exchange cartridge Discovery ${ }^{\circledR}$ DSC-SCX was applied to further purify the crude product. Initially, an activation of the cartridge with methanol $(100 \mathrm{~mL})$ was carried out followed by loading the cartridge with the sample. Then, the elution was performed with the following solvents/solutions: (i) dichloromethane/methanol (5:5), (ii) methanol, and (iii) ammonium hydroxide/methanol ( $2 \%, v / v)$. The fractions obtained from the elution with ammonium hydroxide/methanol $(2 \%, v / v)$ were gathered and the solvent was evaporated under reduced pressure to furnish the xanthones $37,38,39$, and 40 as pure compounds.

For 1-(((4-fluorobenzyl)amino)methyl)-3,4-dimethoxy-9H-xanthen-9-one (37): White powder, (34 mg, 61\% yield); m.p. $163-165{ }^{\circ} \mathrm{C} .{ }^{1} \mathrm{H}-\mathrm{NMR}\left(\mathrm{CDCl}_{3}, 300.13 \mathrm{MHz}\right): \delta=8.28(1 \mathrm{H}, \mathrm{dd}, J=8.0$ and $1.6 \mathrm{~Hz}, \mathrm{H}-8), 7.71(1 \mathrm{H}, \mathrm{ddd}, J=8.5,7.0$, and $1.6 \mathrm{~Hz}, \mathrm{H}-6), 7.55(1 \mathrm{H}, \mathrm{dd}, J=8.5$ and $0.8 \mathrm{~Hz}, \mathrm{H}-5), 7.40$ $(1 \mathrm{H}, \mathrm{ddd}, J=8.0,7.0$, and $0.8 \mathrm{~Hz}, \mathrm{H}-7), 7.36\left(2 \mathrm{H}, \mathrm{m}, \mathrm{H}-5^{\prime}\right), 7.01\left(2 \mathrm{H}, \mathrm{m}, \mathrm{H}-4^{\prime}\right), 6.96(1 \mathrm{H}, \mathrm{s}, \mathrm{H}-2), 4.30$ $\left(2 \mathrm{H}, \mathrm{s}, \mathrm{H}-1^{\prime}\right), 4.01\left(3 \mathrm{H}, \mathrm{s}, 4-\mathrm{OCH}_{3}\right), 4.01\left(3 \mathrm{H}, \mathrm{s}, 3-\mathrm{OCH}_{3}\right), 3.85\left(2 \mathrm{H}, \mathrm{s}, \mathrm{H}-2^{\prime}\right) \mathrm{ppm} ;{ }^{13} \mathrm{C}-\mathrm{NMR}\left(\mathrm{CDCl}_{3}\right.$, $75.47 \mathrm{MHz}$ ): $\delta=178.1$ (C-9), 160.3 (C-6'), 156.3 (C-3), 155.3 (C-10a), 152.2 (C-4a), 138.6 (C-4), 135.9 (C-3'), 135.7 (C-1), 134.5 (C-6), 129.8 (C-5'), 126.7 (C-8), 124.0 (C-7), 122.2 (C-8a), 117.7 (C-5), 115.3 (C-4'), $114.7(\mathrm{C}-9 \mathrm{a}), 110.9(\mathrm{C}-2), 61.5\left(4-\mathrm{OCH}_{3}\right), 56.3\left(3-\mathrm{OCH}_{3}\right), 53.3\left(\mathrm{C}-1^{\prime}\right), 52.5\left(\mathrm{C}-2^{\prime}\right) \mathrm{ppm}$. HRMS $\left(\mathrm{ESI}^{+}\right): \mathrm{m} / \mathrm{z}$ $\left[\mathrm{C}_{23} \mathrm{H}_{20} \mathrm{FNO}_{4}+\mathrm{H}\right]^{+}$calcd. for $\left[\mathrm{C}_{23} \mathrm{H}_{21} \mathrm{FNO}_{4}\right]$ : 394.14491; found: 394.14410 .

For 1-(((4-chlorobenzyl)amino)methyl)-3,4-dimethoxy-9H-xanthen-9-one (38): Light yellow powder (35 mg, 61\% yield); m.p. $162-163{ }^{\circ} \mathrm{C} .{ }^{1} \mathrm{H}-\mathrm{NMR}\left(\mathrm{CDCl}_{3}, 300.13 \mathrm{MHz}\right): \delta=8.25(1 \mathrm{H}$, dd, $J=8.0$ and $1.6 \mathrm{~Hz}, \mathrm{H}-8), 7.79(1 \mathrm{H}, \mathrm{ddd}, J=8.5,7.0$, and $1.6 \mathrm{~Hz}, \mathrm{H}-6), 7.66\left(2 \mathrm{H}, \mathrm{m}, \mathrm{H}-5^{\prime}\right), 7.60(1 \mathrm{H}, \mathrm{dd}, J$ $=8.5$ and $0.9 \mathrm{~Hz}, \mathrm{H}-5), 7.43(1 \mathrm{H}, \mathrm{ddd}, J=8.0,7.0$, and $0.9 \mathrm{~Hz}, \mathrm{H}-7), 7.39(1 \mathrm{H}, \mathrm{s}, \mathrm{H}-2), 7.38\left(2 \mathrm{H}, \mathrm{m}, \mathrm{H}-4^{\prime}\right)$, $4.53\left(2 \mathrm{H}, \mathrm{s}, \mathrm{H}-2^{\prime}\right) ; 4.33\left(2 \mathrm{H}, \mathrm{s}, \mathrm{H}-1^{\prime}\right), 4.07\left(3 \mathrm{H}, \mathrm{s}, 4-\mathrm{OCH}_{3}\right), 4.01\left(3 \mathrm{H}, \mathrm{s}, 3-\mathrm{OCH}_{3}\right) \mathrm{ppm} ;{ }^{13} \mathrm{C}-\mathrm{NMR}\left(\mathrm{CDCl}_{3}\right.$, $75.47 \mathrm{MHz}): \delta=179.6$ (C-9), 157.0 (C-3), 155.5 (C-10a), 152.0 (C-4a), 137.7 (C-4), 135.8 (C-1), 135.6 (C-6), $131.7\left(\mathrm{C}-5^{\prime}\right), 129.5\left(\mathrm{C}-4^{\prime}\right), 129.4\left(\mathrm{C}-3^{\prime}\right), 127.3$ (C-6'), 126.6 (C-8), 124.6 (C-7), 121.3 (C-8a), 117.9 (C-5), $115.5(\mathrm{C}-2), 114.8(\mathrm{C}-9 \mathrm{a}), 61.6\left(4-\mathrm{OCH}_{3}\right), 57.1\left(3-\mathrm{OCH}_{3}\right), 51.3\left(\mathrm{C}-1^{\prime}\right), 50.7\left(\mathrm{C}-2^{\prime}\right) \mathrm{ppm}$. HRMS $\left(\mathrm{ESI}^{+}\right): \mathrm{m} / \mathrm{z}$ $\left[\mathrm{C}_{23} \mathrm{H}_{20} \mathrm{ClNO}_{4}+\mathrm{H}\right]^{+}$calcd. for $\left[\mathrm{C}_{23} \mathrm{H}_{21} \mathrm{ClNO}_{4}\right]: 410.11536$; found: 410.11466 .

For (R)-1-(((1-(4-chlorophenyl)ethyl)amino)methyl)-3,4-dimethoxy-9H-xanthen-9-one (39): White powder (39 mg, $65 \%$ yield); m.p. $163-164{ }^{\circ} \mathrm{C} .{ }^{1} \mathrm{H}-\mathrm{NMR}\left(\mathrm{CDCl}_{3}, 300.13 \mathrm{MHz}\right): \delta=8.26(1 \mathrm{H}, \mathrm{dd}, J=$ 8.0 and $1.6 \mathrm{~Hz}, \mathrm{H}-8), 7.79(1 \mathrm{H}, \mathrm{ddd}, J=8.5,7.0$, and $1.6 \mathrm{~Hz}, \mathrm{H}-6), 7.70\left(2 \mathrm{H}, \mathrm{m}, \mathrm{H}-6^{\prime}\right), 7.59(1 \mathrm{H}, \mathrm{dd}$, $J=8.5$ and $0.8 \mathrm{~Hz}, \mathrm{H}-5), 7.43(1 \mathrm{H}, \mathrm{ddd}, J=8.0,7.0$, and $0.8 \mathrm{~Hz}, \mathrm{H}-7), 7.42\left(2 \mathrm{H}, \mathrm{m}, \mathrm{H}-5^{\prime}\right), 7.25(1 \mathrm{H}$, 
s, H-2), $4.54\left(2 \mathrm{H}, \mathrm{s}, \mathrm{H}-1^{\prime}\right) ; 4.27\left(1 \mathrm{H}, \mathrm{q}, J=6.8 \mathrm{~Hz}, \mathrm{H}-1^{\prime}\right), 4.04\left(3 \mathrm{H}, \mathrm{s}, 4-\mathrm{OCH}_{3}\right), 4.01\left(3 \mathrm{H}, \mathrm{s}, 3-\mathrm{OCH}_{3}\right)$, $1.83\left(3 \mathrm{H}, \mathrm{d}, J=6.8 \mathrm{~Hz}, \mathrm{H}-3^{\prime}\right)$ ppm; ${ }^{13} \mathrm{C}-\mathrm{NMR}\left(\mathrm{CDCl}_{3}, 75.47 \mathrm{MHz}\right): \delta=179.6(\mathrm{C}-9), 156.8(\mathrm{C}-3), 155.4$ (C-10a), 151.9 (C-4a), 137.6 (C-4), 135.5 (C-6), 134.5 (C-1), 131.8 (C-7'), 129.8 (C-6'), 129.5 (C-5'), 127.3 $\left(\mathrm{C}-4^{\prime}\right), 126.6$ (C-8), 124.6 (C-7), 121.3 (C-8a), 117.9 (C-5), 115.6 (C-2), 114.9 (C-9a), 61.6 (4-OCH ( $_{3}, 58.9$ $\left(\mathrm{C}-2^{\prime}\right), 57.0\left(3-\mathrm{OCH}_{3}\right), 50.2\left(\mathrm{C}-1^{\prime}\right), 20.2\left(\mathrm{C}-3^{\prime}\right)$ ppm. HRMS $\left(\mathrm{ESI}^{+}\right): m / z\left[\mathrm{C}_{24} \mathrm{H}_{22} \mathrm{ClNO}_{4}+\mathrm{H}\right]^{+}$calcd. for [C $\left.{ }_{24} \mathrm{H}_{23} \mathrm{ClNO}_{4}\right]$ : 424.13101; found: 424.13018 .

For 1-(((4-bromobenzyl)amino)methyl)-3,4-dimethoxy-9H-xanthen-9-one (40): White powder (47 mg, 73\% yield); m.p. $161-162{ }^{\circ} \mathrm{C} .{ }^{1} \mathrm{H}-\mathrm{NMR}\left(\mathrm{CDCl}_{3}, 300.13 \mathrm{MHz}\right): \delta=8.27(1 \mathrm{H}, \mathrm{dd}, J=8.0$ and $1.6 \mathrm{~Hz}, \mathrm{H}-8), 7.73(1 \mathrm{H}, \mathrm{ddd}, J=8.5,7.0$, and $1.6 \mathrm{~Hz}, \mathrm{H}-6), 7.58(1 \mathrm{H}, \mathrm{dd}, J=8.5$ and $0.8 \mathrm{~Hz}, \mathrm{H}-5), 7.48$ $\left(2 \mathrm{H}, \mathrm{m}, \mathrm{H}-5^{\prime}\right), 7.39\left(2 \mathrm{H}, \mathrm{m}, \mathrm{H}-4^{\prime}\right), 7.38(1 \mathrm{H}, \mathrm{ddd}, J=8.0,7.0$, and $0.8 \mathrm{~Hz}, \mathrm{H}-7), 7.08(1 \mathrm{H}, \mathrm{s}, \mathrm{H}-2), 4.31$ $\left(2 \mathrm{H}, \mathrm{s}, \mathrm{H}-1^{\prime}\right) ; 4.01\left(3 \mathrm{H}, \mathrm{s}, 4-\mathrm{OCH}_{3}\right), 4.01\left(3 \mathrm{H}, \mathrm{s}, 3-\mathrm{OCH}_{3}\right), 3.88\left(2 \mathrm{H}, \mathrm{s}, \mathrm{H}-2^{\prime}\right) \mathrm{ppm} ;{ }^{13} \mathrm{C}-\mathrm{NMR}\left(\mathrm{CDCl}_{3}\right.$, $75.47 \mathrm{MHz}): \delta=178.6$ (C-9), 156.5 (C-3), 155.3 (C-10a), 152.2 (C-4a), 136.4 (C-4), 136.2 (C-1), 134.9 (C-6), $131.8\left(\mathrm{C}-5^{\prime}\right), 130.7\left(\mathrm{C}-4^{\prime}\right), 128.4\left(\mathrm{C}-3^{\prime}\right), 126.6$ (C-8), 124.2 (C-7), 121.9 (C-8a), 121.8 (C-6'), 117.7 (C-5), $114.7(\mathrm{C}-9 \mathrm{a}), 112.5(\mathrm{C}-2), 61.6\left(4-\mathrm{OCH}_{3}\right), 56.7\left(3-\mathrm{OCH}_{3}\right), 52.7\left(\mathrm{C}-1^{\prime}\right), 52.0\left(\mathrm{C}-2^{\prime}\right)$ ppm. HRMS $\left(\mathrm{ESI}^{+}\right): \mathrm{m} / \mathrm{z}$ $\left[\mathrm{C}_{23} \mathrm{H}_{20} \mathrm{BrNO}_{4}+\mathrm{H}\right]^{+}$calcd. for $\left[\mathrm{C}_{23} \mathrm{H}_{21} \mathrm{BrNO}_{4}\right]$ : 454.06485 ; found: 454.06385 .

\subsection{Biological Evaluation}

\subsubsection{Yeast Strains and Growth Conditions}

For the yeast assay, the previously obtained Saccharomyces cerevisiae cells co-expressing human p53 or human MDM2, as well as yeast control (transformed with empty vectors) [30,31], were used. To induce expression of human proteins, yeast cells were grown in selective induction medium with $2 \%$ $(w / w)$ galactose and $2 \%(w / w)$ raffinose, in the presence of $1-20 \mu \mathrm{M}$ of xanthones $30-40$ or $0.1 \%$ DMSO, at $30{ }^{\circ} \mathrm{C}$ under continuous orbital shaking (200 rpm) for approximately $42 \mathrm{~h}$, as described [30,31]. Yeast cell growth was analyzed by counting the number of colony-forming units (CFU) after 2 days incubation at $30^{\circ} \mathrm{C}$ on Sabouraud Dextrose Agar plates from Liofilchem (Frilabo, Porto, Portugal). Results were estimated considering $100 \%$ growth as the number of CFU obtained with untreated yeast co-expressing p53 and MDM2.

\subsubsection{Human Cancer Cell Lines and Culture Conditions}

Human colon adenocarcinoma HCT116 cell lines expressing wt p53 (HCT116 p53+/+) and its p53-null isogenic derivative (HCT116 p53-/-) were provided by B. Vogelstein (The Johns Hopkins Kimmel Cancer Center, Baltimore, MD, USA). Human liver HepG2 carcinoma cell lines were purchased from ATCC (Rockville, MD, USA). Cancer cells were cultured in RPMI-1640 medium with ultraglutamine (Lonza, VWR, Carnaxide, Portugal), and supplemented with 10\% fetal bovine serum (FBS; Merck Millipore, VWR). Cells were maintained at $37^{\circ} \mathrm{C}$ in a humidified atmosphere of $5 \% \mathrm{CO}_{2}$.

\subsubsection{Cell Proliferation Assay}

Cell proliferation was determined using the SRB assay, as described [30,31]. Briefly, cells were seeded in 96-well plates at $5.0 \times 10^{3}$ cells/well for HCT116 p53 ${ }^{+/+}$cells and $4.0 \times 10^{3}$ cells/well for HepG2 and $24 \mathrm{~h}$ later treated with serial dilutions (3.13-50 $\mu \mathrm{M})$ of xanthone 37 or $0.25 \%$ DMSO for 48 $\mathrm{h}$. $\mathrm{IC}_{50}$ values were determined from the concentration-response curves.

\subsubsection{Colony Formation Assay}

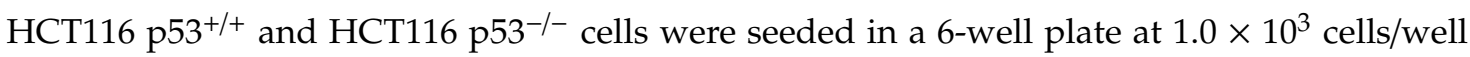
and treated with $3,4,5,7$, and $10 \mu \mathrm{M}$ of xanthone 37 or DMSO at the time of seeding. After 11 days incubation, colonies were fixed using $10 \%$ of methanol and $10 \%$ acetic acid for 10 min and stained with $0.5 \%$ crystal violet (Sigma-Aldrich) in 1:1 methanol/water for $15 \mathrm{~min}$. Colonies with more than 20 cells were counted. 


\subsubsection{Cell Cycle Analysis}

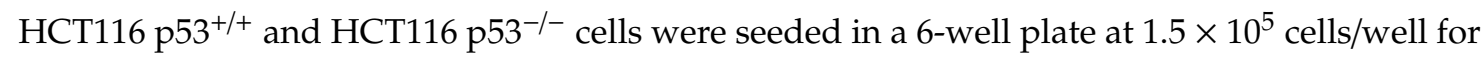
$24 \mathrm{~h}$ and treated with 10 and $20 \mu \mathrm{M}$ of xanthone 37 or DMSO for $24 \mathrm{~h}$. Cells were collected, fixed, and stained with propidium iodide (Fluka, Sigma-Aldrich). Cell cycle was analyzed by flow cytometry, as described [45].

\subsubsection{Western Blot Analysis}

HCT116 p53 $3^{+/+}$were seeded in a 6-well plate at $1.5 \times 10^{5}$ cells/well for $24 \mathrm{~h}$ and treated with 10 and $20 \mu \mathrm{M}$ of xanthone 37 or DMSO for $24 \mathrm{~h}$. Total protein extracts of cancer cells were obtained and analyzed by Western blot, as described [45]. Membranes were probed with a mouse monoclonal anti-p53 (DO-1), anti-MDM2 (D-12), or with a rabbit polyclonal anti-p21 (C-19), followed by an anti-mouse or anti-rabbit horseradish-peroxidase (HRP)-conjugated secondary antibody. For loading control, membranes were stripped and re-probed with mouse monoclonal anti-GAPDH (6C5). All antibodies were purchased from Santa Cruz Biotechnology (Frilabo, Porto, Portugal). The signal was detected with enhanced chemiluminescence (ECL) Amersham Kit from GE Healthcare (VWR) and with Molecular Imager ${ }^{\circledR}$ ChemiDoc ${ }^{\mathrm{TM}}$ XRS+ System, using Image Lab ${ }^{\mathrm{TM}}$ software.

\subsubsection{Statistical Analysis}

Data's statistical analysis was performed using the Prism 7 program (GraphPad Software Inc., California, USA). Differences between means were tested for significance using one-way ANOVA with Tukey's multiple comparisons test, two-way ANOVA with Sidak's multiple comparisons test, and Student's $t$-test $\left({ }^{*} p<0.05 ; * *<0.01\right)$.

\subsection{In Silico Studies onto MDM2}

The chemical structures of gambogic acid (2), $\alpha$-mangostin (3), 12-hydroxy-2,2-dimethyl-3,4dihydro-2H,6H-pyrano[3,2-b] xanthen-6-one (4), and the xanthones 30-40 were drawn using ChemSketch (Advanced Chemistry Development, Inc. (ACD/Labs), Canada); the structure of known MDM2-p53 inhibitor nutlin-3A (1) was obtained from PubChem [53]. The three-dimensional (3D) structures of the xanthones and 1 were minimized using the ArgusLab version 4.0.1 software for Windows by Hamiltonian (quantum mechanics) using the Parameterized Model number 3 (PM3) semi-empirical method [54]. The 3D structure of MDM2 was extracted from Protein Data Bank (PDB id 4HG7) [50]. Docking simulations involving MDM2 and the small molecules were undertaken in AutoDock Vina (Scripps Research Institute, USA) [51]. AutoDock Vina considered the macromolecular target conformation as a rigid unit, while the ligands were allowed to be flexible and adaptable to the target. Vina explored the lowest binding affinity conformations and returned nine different conformations for each ligand. AutoDock Vina was run using an exhaustiveness of 8 and a grid box with the dimensions of $19.7 \AA, 26.1 \AA$, and $14.1 \AA$, engulfing the binding cavity occupied by the crystallographic nutlin-3A (PDB id 4HG7). Ligand conformations and interactions with the binding cavity were visualized using PyMOL version 1.3 [55]. In order to validate the docking approach for the macromolecular target structure used, nutlin-3A was docked onto the binding cavity of MDM2 using AutoDock Vina, and the obtained docking conformation was compared to crystallographic nutlin-3A (PDB id 4HG7) using RMSD (not shown). Docking scores of xanthones and positive controls were compared.

\section{Conclusions}

An alternative and efficient strategy for the preparation of carbaldehydic xanthones was successfully developed. The use of a precursor with a methyl substituent at position C-1 revealed to be crucial for the optimization of the synthesis of 5 . The newly described approach required lower reaction times and enabled the preparation of xanthone 5 in a higher global yield. In this work, a series of eleven 
aminated xanthones (30-40) possessing a 3,4-dioxygenated pattern of substitution was efficiently constructed in moderate to good yields. From this group of compounds, xanthone 37 was identified for the first time as a putative p53-activating agent, using a yeast-based screening assay. Xanthone 37 was revealed to inhibit the growth of human HCT116 $\mathrm{p} 53^{+/+}$colon cancer cells, being that this effect is associated with cell cycle arrest through activation of the p53 pathway. Nevertheless, further studies are required to confirm the mechanism of action of 37 , which may lead to the identification of a novel xanthone derivative with promising antitumor activity.

These results demonstrated the potential usefulness of coupling amine-containing structural motifs of known MDM2-p53 disruptors into the 3,4-dioxygenated xanthone scaffold as a starting point for the design of novel and improved p53-activating agents with antitumor activity and drug-like properties.

Supplementary Materials: The following are available online. Figure S1-S15: HRMS spectra of the xanthone derivatives 5 and 27-40. Figure S16-S45: $1 \mathrm{H}$ - and ${ }^{13} \mathrm{C}-\mathrm{NMR}$ spectra of the xanthone derivatives $\mathbf{5}$ and 27-40.

Author Contributions: A.L. performed the in silico studies and the synthesis of xanthones and wrote the manuscript. A.L., A.S.G., and J.B.L. performed biological experiments and analyzed the data. P.B. contributed to the experimental synthetic work. M.E.S. and L.S. conceived and designed the study, coordinated the experimental work, and wrote the manuscript. A.P. coordinated the in silico studies. M.M.M.P., M.E.S., and L.S. provided financial support for the study, analyzed the data, and wrote the manuscript.

Funding: The authors thank to national funds provided by FCT-Foundation for Science and Technology and European Regional Development Fund (ERDF) and COMPETE under the Strategic Funding UID/Multi/ 04423/2019, UID/QUI/50006/2019 (UCIBIO/REQUIMTE) the projects (3599-PPCDT) PTDC/DTP-FTO/1981/2014POCI-01-0145-FEDER-016581, POCI-01-0145-FEDER-028736, and PTDC/MAR-BIO/4694/2014 (POCI-01-0145FEDER-016790; 3599-PPCDT). FCT fellowships: PD/BD/114046/2015 (A.S. Gomes), SFRH/BD/128673/2017 (J. B. Loureiro), and the Programa Operacional Capital Humano (POCH), specifically the BiotechHealth Programme (PD/00016/2012).

Conflicts of Interest: The authors declare no conflict of interest. The funders had no role in the design of the study; in the collection, analyses, or interpretation of data; in the writing of the manuscript, or in the decision to publish the results.

\section{References}

1. Lane, D.P. Cancer. p53, guardian of the genome. Nature 1992, 358, 15-16. [CrossRef]

2. Shaw, P.H. The role of p53 in cell cycle regulation. Pathol. Res. Pract. 1996, 192, 669-675. [CrossRef]

3. Toledo, F.; Wahl, G.M. Regulating the p53 pathway: In vitro hypotheses, in vivo veritas. Nat. Rev. Cancer 2006, 6, 909-923. [CrossRef] [PubMed]

4. Vazquez, A.; Bond, E.E.; Levine, A.J.; Bond, G.L. The genetics of the p53 pathway, apoptosis and cancer therapy. Nat. Rev. Drug Discov. 2008, 7, 979-987. [CrossRef] [PubMed]

5. Rufini, A.; Tucci, P.; Celardo, I.; Melino, G. Senescence and aging: The critical roles of p53. Oncogene 2013, 32, 5129-5143. [CrossRef] [PubMed]

6. Williams, A.B.; Schumacher, B. p53 in the DNA-damage-repair process. Cold Spring Harb. Perspect. Med. 2016, 6, a026070. [CrossRef]

7. Vogelstein, B.; Lane, D.; Levine, A.J. Surfing the p53 network. Nature (London, U.K.) 2000, 408, 307-310. [CrossRef] [PubMed]

8. Hainaut, P.; Hollstein, M. p53 and human cancer: The first ten thousand mutations. Adv. Cancer Res. 1999, $77,81-137$.

9. Wang, X. p53 regulation: Teamwork between RING domains of MDM2 and MDMX. Cell Cycle 2011, 10, 4225-4229. [CrossRef] [PubMed]

10. Wu, X.; Bayle, J.H.; Olson, D.; Levine, A.J. The p53-MDM2 autoregulatory feedback loop. Genes Dev. 1993, 7, 1126-1132. [CrossRef] [PubMed]

11. Momand, J.; Wu, H.H.; Dasgupta, G. MDM2 - master regulator of the p53 tumor suppressor protein. Gene 2000, 242, 15-29. [CrossRef]

12. Momand, J.; Zambetti, G.P.; Olson, D.C.; George, D.; Levine, A.J. The MDM2 oncogene product forms a complex with the p53 protein and inhibits p53-mediated transactivation. Cell 1992, 69, 1237-1245. [CrossRef]

13. Oliner, J.D.; Pietenpol, J.A.; Thiagalingam, S.; Gyuris, J.; Kinzler, K.W.; Vogelstein, B. Oncoprotein MDM2 conceals the activation domain of tumor supressor p53. Nature (London, U.K.) 1993, 362, 857-860. [CrossRef] 
14. Roth, J.; Dobbelstein, M.; Freedman, D.A.; Shenk, T.; Levine, A.J. Nucleo-cytoplasmic shuttling of the HDM2 oncoprotein regulated the levels of the $\mathrm{p} 53$ protein via a pathway used by the human immunodeficiency vírus ver protein. EMBO J. 1998, 17, 554-564. [CrossRef]

15. Haupt, Y.; Maya, R.; Kazaz, A.; Oren, M. MDM2 promotes the rapid degradation of p53. Nature 1997, 387, 296-299. [CrossRef] [PubMed]

16. Pant, V.; Lozano, G. Limiting the power of p53 through the ubiquitin proteasome pathway. Genes Dev. 2014, 28, 1739-1751. [CrossRef] [PubMed]

17. Zhao, Y.; Aguilar, A.; Bernard, D.; Wang, S. Small-molecule inhibitors of the MDM2-p53 protein-protein interaction (MDM2 inhibitors) in clinical trials for cancer treatment: Miniperspective. J. Med. Chem. 2014, 58, 1038-1052. [CrossRef] [PubMed]

18. Wang, S.; Zhao, Y.; Aguilar, A.; Bernard, D.; Yang, C.Y. Targeting the MDM2-p53 protein-protein interaction for new cancer therapy: Progress and challenges. Cold Spring Harb. Perspect. Med. 2017, 7, a026245. [CrossRef]

19. Vassilev, L.T.; Vu, B.T.; Graves, B.; Carvajal, D.; Podlaski, F.; Filipovic, Z.; Kong, N.; Kammlott, U.; Lukacs, C.; Klein, C.; Fotouhi, N.; Liu, E.A. In vivo activation of the p53 pathway by small-molecule antagonists of MDM2. Science 2004, 303, 844-848. [CrossRef]

20. Lemos, A.; Leão, M.; Soares, J.; Palmeira, A.; Pinto, M.; Saraiva, L.; Sousa, M.E. Medicinal chemistry strategies to disrupt p53-MDM2/MDMX interaction. Med. Res. Rev. 2016, 36, 789-844. [CrossRef]

21. Tisato, V.; Voltan, R.; Gonelli, A.; Secchiero, P.; Zauli, G. MDM2/X inhibitors under clinical evaluation: Perspectives for the management of hematological malignancies and pediatric cancer. J. Hematol. Oncol. 2017, 10, 133. [CrossRef] [PubMed]

22. Pinto, M.M.M.; Sousa, M.E.; Nascimento, M.S. Xanthone derivatives: New insights in biological activities. Curr. Med. Chem. 2005, 12, 2517-2538. [CrossRef] [PubMed]

23. Pouli, N.; Marakos, P. Fused xanthone derivatives as antiproliferative agents. Anticancer Agents Med. Chem. 2009, 9, 77-98. [CrossRef]

24. Pedro, M.; Cerqueira, F.; Sousa, M.E.; Nascimento, M.S.J.; Pinto, M. Xanthones as inhibitors of growth of human cancer cell lines and their effects on the proliferation of human lymphocytes in vitro. Bioorg. Med. Chem. 2002, 10, 3725-3730. [CrossRef]

25. Sousa, E.P.; Silva, A.M.S.; Pinto, M.M.M.; Pedro, M.M.; Cerqueira, F.A.M.; Nascimento, M.S.J. Isomeric kielcorins and dihydroxyxanthones: Synthesis, structure elucidation, and inhibitory activities of growth of human cancer cell lines and on the proliferation of human lymphocytes in vitro. Helv. Chim. Acta 2002, 85, 2862-2876. [CrossRef]

26. Castanheiro, R.A.; Pinto, M.M.; Silva, A.M.; Cravo, S.M.; Gales, L.; Damas, A.M.; Nazareth, N.; Nascimento, M.S.J.; Eaton, G. Dihydroxyxanthones prenylated derivatives: Synthesis, structure elucidation, and growth inhibitory activity on human tumor cell lines with improvement of selectivity for MCF-7. Bioorg. Med. Chem. 2007, 15, 6080-6088. [CrossRef]

27. Sousa, E.; Paiva, A.; Nazareth, N.; Gales, L.; Damas, A.M.; Nascimento, M.S.J.; Pinto, M. Bromoalkoxyxanthones as promising antitumor agents: Synthesis, crystal structure and effect on human tumor cell lines. Eur. J. Med. Chem. 2009, 44, 3830-3835. [CrossRef]

28. Palmeira, A.; Paiva, A.; Sousa, E.; Seca, H.; Almeida, G.M.; Lima, R.T.; Fernandes, M.X.; Pinto, M.; Vasconcelos, M.H. Insights into the in vitro antitumor mechanism of action of a new pyranoxanthone. Chem. Biol. Drug Des. 2010, 76, 43-58. [CrossRef]

29. Paiva, A.M.; Sousa, M.E.; Camoes, A.; Nascimento, M.S.J.; Pinto, M.M.M. Prenylated xanthones: Antiproliferative effects and enhancement of the growth inhibitory action of 4-hydroxytamoxifen in estrogen receptor-positive breast cancer cell line. Med. Chem. Res. 2012, 21, 552-558. [CrossRef]

30. Leão, M.; Gomes, S.; Pedraza-Chaverri, J.; Machado, N.; Sousa, E.; Pinto, M.; Inga, A.; Pereira, C.; Saraiva, L. $\alpha$-Mangostin and gambogic acid as potential inhibitors of the p53-MDM2 interaction revealed by a yeast-based approach. J. Nat. Prod. 2013, 76, 774-778. [CrossRef]

31. Leão, M.; Pereira, C.; Bisio, A.; Ciribilli, Y.; Paiva, A.M.; Machado, N.; Palmeira, A.; Fernandes, M.X.; Sousa, E.; Pinto, M.; Inga, A.; Saraiva, L. Discovery of a new small-molecule inhibitor of p53-MDM2 interaction using a yeast-based approach. Biochem. Pharmacol. 2013, 85, 1234-1245. [CrossRef] 
32. Fernandes, C.; Masawang, K.; Tiritan, M.E.; Sousa, E.; de Lima, V.; Afonso, C.; Bousbaa, H.; Sudprasert, W.; Pedro, M.; Pinto, M. New chiral derivatives of xanthones: Synthesis and investigation of enantioselectivity as inhibitors of growth of human tumor cell lines. Bioorg. Med. Chem. 2014, 22, 1049-1062. [CrossRef]

33. Barbosa, J.; Lima, R.T.; Sousa, D.; Gomes, A.S.; Palmeira, A.; Seca, H.; Choosang, K.; Pakkong, P.; Bousbaa, H.; Pinto, M.M.; et al. Screening a small library of xanthones for antitumor activity and identification of a hit compound which induces apoptosis. Molecules 2016, 21, 81. [CrossRef]

34. Cidade, H.; Rocha, V.; Palmeira, A.; Marques, C.; Tiritan, M.E.; Ferreira, H.; Lobo, J.S.; Almeida, I.F.; Sousa, M.E.; Pinto, M. In silico and in vitro antioxidant and cytotoxicity evaluation of oxygenated xanthone derivatives. Arab. J. Chem. 2017. [CrossRef]

35. Alves, A.; Correia-da-Silva, M.; Nunes, C.; Campos, J.; Sousa, E.; Silva, P.M.A.; Bousbaa, H.; Rodrigues, F.; Ferreira, D.; Costa, P.C.; et al. Discovery of a new xanthone against glioma: Synthesis and development of (pro)liposome formulations. Molecules 2019, 24, 409. [CrossRef]

36. Gomes, S.; Raimundo, L.; Soares, J.; Loureiro, J.B.; Leão, M.; Ramos, H.; Monteiro, M.N.; Lemos, A.; Moreira, J.; Pinto, M.; et al. New inhibitor of the TAp73 interaction with MDM2 and mutant p53 with promising antitumor activity against neuroblastoma. Cancer Lett. 2019, 446, 90-102. [CrossRef]

37. Liu, J.; Zhou, F.; Zhang, L.; Wang, H.; Zhang, J.; Zhang, C.; Jiang, Z.; Li, Y.; Liu, Z.; Chen, H. DMXAA-pyranoxanthone hybrids enhance inhibition activities against human cancer cells with multi-target functions. Eur. J. Med. Chem. 2018, 143, 1768-1778. [CrossRef]

38. Hardcastle, I.R.; Liu, J.; Valeur, E.; Watson, A.; Ahmed, S.U.; Blackburn, T.J.; Bennaceur, K.; Clegg, W.; Drummond, C.; Endicott, J.A.; et al. Isoindolinone inhibitors of the murine double minute 2 (MDM2)-p53 protein-protein interaction: Structure-activity studies leading to improved potency. J. Med. Chem. 2011, 54, 1233-1243. [CrossRef]

39. Twarda-Ciapa, A.; Krzanik, S.; Kubica, K.; Guzik, K.; Labuzek, B.; Neochoritis, C.G.; Khoury, K.; Kowalska, K.; Czub, M.; Dubin, G.; et al. 1,4,5-Trisubstituted imidazole-based p53-MDM2/MDMX antagonists with aliphatic linkers for conjugation with biological carriers. J. Med. Chem. 2017, 60, 4234-4244. [CrossRef]

40. Gicquel, M.; Gomez, C.; Alvarez, M.C.G.; Pamlard, O.; Guérineau, V.; Jacquet, E.; Bignon, J.; Voituriez, A.; Marinetti, A. Inhibition of p53-murine double minute 2 (MDM2) interactions with 3,3'-spirocyclopentene oxindole derivatives. J. Med. Chem. 2018, 61, 9386-9392. [CrossRef]

41. Quillinan, A.J.; Schelnmann, F. Studies in the xanthone series. Part XII. A general synthesis of polyoxygenated xanthones from benzophenone precursors. J. Chem. Soc. Perkin Trans. 1973, 1, 1329-1337. [CrossRef]

42. Resende, D.I.S.P.; Pereira-Terra, P.; Inácio, Â.S.; da Costa, P.M.; Pinto, E.; Sousa, E.; Pinto, M.M.M. Lichen xanthones as models for new antifungal agents. Molecules 2018, 23, 2617. [CrossRef]

43. Martins, E.; Silva, V.; Lemos, A.; Palmeira, A.; Puthongking, P.; Sousa, E.; Rocha-Pereira, C.; Ghanem, C.I.; Carmo, H.; Remião, F.; et al. Newly synthesized oxygenated xanthones as potential P-glycoprotein activators: In vitro, ex vivo, and in silico studies. Molecules 2019, 24, 707. [CrossRef]

44. Soares, J.; Espadinha, M.; Raimundo, L.; Ramos, H.; Gomes, A.S.; Gomes, S.; Loureiro, J.B.; Inga, A.; Reis, F.; Gomes, C.; et al. DIMP53-1: A novel small-molecule dual inhibitor of p53-MDM2/X interactions with multifunctional p53-dependent anticancer properties. Mol. Oncol. 2017, 11, 612-627. [CrossRef]

45. Soares, J.; Pereira, N.A.; Monteiro, Â.; Leão, M.; Bessa, C.; dos Santos, D.J.; Raimundo, L.; Queiroz, G.; Bisio, A.; Inga, A.; et al. Oxazoloisoindolinones with in vitro antitumor activity selectively activate a p53-pathway through potential inhibition of the p53-MDM2 interaction. Eur. J. Pharm. Sci. 2015, 66, 138-147. [CrossRef]

46. Soares, J.; Raimundo, L.; Pereira, N.A.; dos Santos, D.J.; Pérez, M.; Queiroz, G.; Leão, M.; Santos, M.M.M.; Saraiva, L. A tryptophanol-derived oxazolopiperidone lactam is cytotoxic against tumors via inhibition of p53 interaction with murine double minute proteins. Pharmacol. Res. 2015, 95-96, 42-52. [CrossRef]

47. Chen, L.; Yin, H.; Farooqi, B.; Sebti, S.; Hamilton, A.D.; Chen, J. p53 $\alpha$-helix mimetics antagonize p53/MDM2 interaction and activate p53. Mol. Cancer Ther. 2005, 4, 1019-1025. [CrossRef]

48. Kalid, O.; Ben-Tal, N. Study of MDM2 binding to p53-analogues: Affinity, helicity, and applicability to drug design. J. Chem. Inf. Model. 2009, 49, 865-876. [CrossRef]

49. Kussie, P.H.; Gorina, S.; Marechal, V.; Elenbaas, B.; Moreau, J.; Levine, A.J.; Pavletich, N.P. Structure of the MDM2 oncoprotein bound to the p53 tumor suppressor transactivation domain. Science 1996, 274, 948-953. [CrossRef] 
50. Anil, B.; Riedinger, C.; Endicott, J.A.; Nobie, M.E. The structure of an MDM2-nutlin-3a complex solved by the use of a validated MDM2 surface-entropy reduction mutant. Acta Crystallogr. D Biol. Crystallogr. 2013, 69, 1358-1366. [CrossRef]

51. Trott, O.; Olson, A.J. AutoDock Vina: Improving the speed and the accuracy of docking with a new scoring function, efficient optimization and multithreading. J. Comput. Chem. 2010, 31, 455-461. [CrossRef] [PubMed]

52. Bharatham, N.; Bharatham, K.; Shelat, A.A.; Bashford, D. Ligand binding mode prediction by docking: MDM2/MDMX inhibitors as a case study. J. Chem. Inf. Model. 2014, 54, 648-659. [CrossRef] [PubMed]

53. Wang, Y.; Xiao, J.; Sujek, T.O.; Zhang, J.; Wang, J.; Bryant, S.H. PubChem: A public information system for analyzing bioactivities of small molecules. Nucleic Acids Res. 2009, 37, 623-633. [CrossRef] [PubMed]

54. Kini, R.M.; Evans, H.J. Molecular modeling of proteins: A strategy for energy minimization by molecular mechanics in the AMBER force field. J. Biomol. Struct. Dyn. 1991, 9, 475-488. [CrossRef] [PubMed]

55. Seeliger, D.; de Groot, B.L. Ligand docking and binding site analysis with PyMOL and AutoDock/Vina. J. Comput. Aided Mol. Des. 2010, 24, 417-422. [CrossRef] [PubMed]

Sample Availability: Samples of the compounds 5, 16-40 are available from the authors.

(C) 2019 by the authors. Licensee MDPI, Basel, Switzerland. This article is an open access article distributed under the terms and conditions of the Creative Commons Attribution (CC BY) license (http://creativecommons.org/licenses/by/4.0/). 